\title{
Yeniçeri Teşrifat Mecmuası (Transkripsiyon ve Değerlendirme)
}

\author{
Abdulkasim Gül \\ Dr. \\ akg_1980@hotmail.com \\ http://orcid.org/0000-0003-3916-1509
}

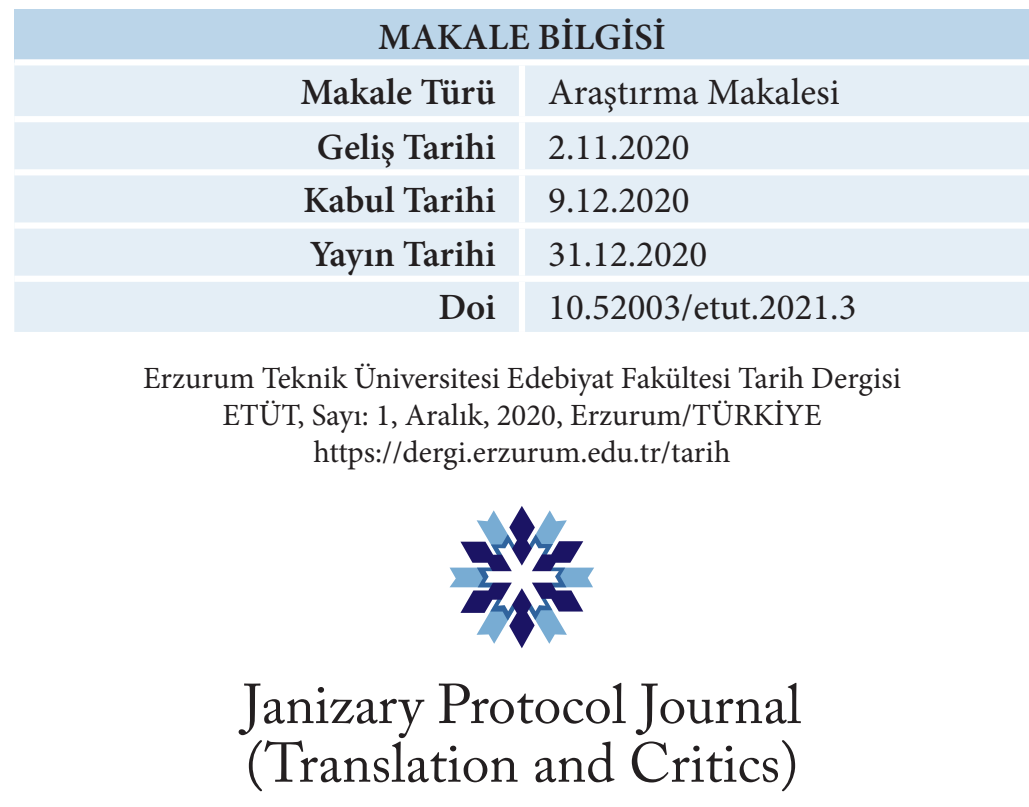

\section{Abdulkasim Gül}

Dr.

akg_1980@hotmail.com

http://orcid.org/0000-0003-3916-1509

\begin{tabular}{|r|l|}
\hline \multicolumn{2}{|c|}{ ARTICLE INFORMATION } \\
\hline Article Types & Research Article \\
\hline Received Date & 2.11 .2020 \\
\hline Accepted Date & 9.12 .2020 \\
\hline Date Published & 31.12 .2020 \\
\hline Doi & $10.52003 /$ etut.2021.3 \\
\hline
\end{tabular}

Erzurum Technical University, Faculty of Letter, History Journal ETUT, Issue: 1, December 2020, Erzurum/TURKEY

https://dergi.erzurum.edu.tr/tarih 


\title{
Yeniçeri Teşrifat Mecmuası (Transkripsiyon ve Değerlendirme)
}

\begin{abstract}
Abdulkasim Gül
Öz

Literatürde Yeniçeri Teşrifat Mecmuası olarak bilinen; yeniçerilerin kışlalarındaki hizmetler, tayinat ve tahsisatları, merasim, adetgelenekleri veyeniçeri ağalarıhakkında bazı malumatlar ihtiva eden mecmua, bu makalenin mevzusudur. Birbirinden farklı hususları konu eden çok kısa metinlerden oluşan mecmuanın bu çalışmada bilinen tek bütün nüshanın çeviriyazısı verilmiş; muhteviyatı olan hususlar, Yeniçeri Ocağı'na ait kanunnameler ve diğer arşiv kayıtlarına uygunluğu bakımından değerlendirmeye tutulmuş; ayrıca yazıldığı ve esas alındığı zaman bakımından tahlil edilmiştir.

Anahtar kelimeler: Mecmua, I. Süleyman, yeniçeri, ağa, kışla.

\section{Janizary Protocol Journal (Translation and Critics)}

Abstract

Known as the Janizary Protocol Journal in the literature; the collections, which contains some information about the services in the barracks of the janissaries, their appointments and allocations, the term, customs-traditions and the janissary lords, is the subject of this article. In this study, the translation of the only known completed copy of the collections, which consists of very short texts containing different issues, is given; The subjects with content have been evaluated in terms of their compliance with the laws of the Janissary Quarry and other archive records; It was also analyzed in terms of the time it was written and taken as basis.
\end{abstract}

Key words: Collections, Suleiman I, janizary, agha, barrack. 


\section{Mecmuanın Muhteviyatına ve Tarihlendirmesine İlişkin Bazı Değerlendirme}

İsmail Hakkı Uzunçarşılı, Kapıkulu Ocakları adlı eserini hazırlarken istifade ettiği ve bir nüshasının hususi kütüphanesinde bulunduğunu gösterdiği mecmuay1, Yeniçeri Teşrifat Mecmuası olarak adlandırmıştır. ${ }^{1}$ Mecmuanın aynı içerikte olduğu anlaşılan 17 varaklık bir nüshası, İstanbul Üniversitesi Nadir Eserler Kütüphanesi'nde (Halis Efendi Koleksiyonu) 3293 numarada kayıtlıdır. Muhtemelen tasnif esnasındamecmuanın üzerine, "Kanuni Devrinde Yeniçeri Ocaklusuna Dair Bazı Merasim 'kaydı düşülmüştür.

Mecmuanınmüellifi bilinmemekte, muhtevasında isim veya yazanı tespite imkân verecek herhangi bir bilgi bulunmamaktadır. Bununla beraber tarihleri farklı ve birbiriyle fazla bağlantısı olmayan mevzulariç̧ermesinden Yeniçeri Ocağı'na mensup birisi tarafından, çeşitli kaynaklardan temin ettiği malumatlarla küçük bir kanun mecmuası oluşturmak için hazırlandığı anlaşılmaktadır.

Yeniçeri Teşrifat Mecmuası'nın; yeniçeri kışlalarının tamir edilip su şebekesi tesisini ve yeniçerilere bazı tayinatlar bağlanmasını gösteren ilk kısmıyla ağa bölüklerinin ihdası, yeniçeri ağasının ocak içinden tayini usulünün kaldırılmasıve görev yapan ağaların sıralandığıson kısmınıayrı olarak veya beraber ihtiva edenrisalelerbazı kütüphanelerde mevcuttur.Mecmuada sıralanmış ağalardan sonra görev yapan ağaların ilavesinden ve bazı düzeltmeleryapılmasından en azından bu kısmın Yeniçeri Teşrifat Mecmuası'ndan istinsah edildiği anlaşılmaktadır.

Her iki kısmı ihtiva edenve ilk kısmı mecmuadakindendaha kısa olan bir risale, Süleymaniye Kütüphanesi, Esad Efendi nr. 3622'de kayıtlıdır. Katalogda "Yeniçeri Ocă̆ının Ahvaline Dair Bir Risale" adıyla kayıtlı kısım yazmanın 48b-

\footnotetext{
${ }^{1}$ İsmail H. Uzunçarşılı bu mecmuayı eserinin başlarında "Yeniçeri Teşkilât Mecmuası" ve "Yeniçeri İlmihali" adlarlarıyla da göstemiş, ancak sonrasında "Yeniçeri Teşrifat Mecmuası" adını kullanmış ve kaynakçada da bu ismi vermiştir. Kapıkulu Ocakları, I, TTK Basımevi, Ankara 1988, 21, 33, 712. Yeniçeriler üzerine tarafımızca hazırlanan "18. Yüzyılda Yeniçeri Teşkilatı" adlı doktora tezinde de mecmua bu adla kullanılmıştır. Uzunçarşıll, mecmuadaki "Sa âdetlü Pâdişâh 'Âlempenâh Hazretleri veyahud Serdâr Vezîr-i a zâm Olub Sefere Gitdiklerinde Büyük Alay Tertîbini Beyân Eder" kısmın1; "Vezîr-i a zâm ile Yeniçeri Ocağı Sefere Gitdiklerinde Büyük Alay Tertibidir ki Zikr Olunur" kısmını; "Ocă̆ın Kānûnu Budur ki Ayda Bir Kere Yeniçeri Ocă̆ı Vezîr-i a'zam Hazretlerine Büyük Kol ile Gitmek Lazım Geldikde" kısmını; "Ramazân-ı Şerîf-i Mübârek Ille ve 'Iyd-ı Şerîf Geldikde Bayramlaşmak İçün Vezîr-i a zam Hazretlerine Bütün Ocak Erbâbı ile Gitmek Lâzım Geldükde" kısmını; "Derbeyân-ı Bayramlaşmak" başlıklı kısmını ve "Defter Oldur ki Yeniçeri Çayırından Ocak Ăgalarına Tevzi “ Olunan Otlukdur ki Zikr Olunur" kısmını eserinde kısmen veya tamamen yeni yazıya aktarılmış olarak vermiştir. Kapıkulu Ocakları, I, 627, 630, 632, 634, 636.
} 
54a varaklarında;Yeniçeri Ağaları Listesi adıyla kayıtlı kısım 54a-56b varaklarındadır. $^{2}$ Mecmuanın sadece ilk kısmından oluşan ve bazı farklılıklarıbulunan diğer bir risale Türk Tarih Kurumu Kütüphanesi'nde Y/228 katalog numarasıyla ve Avusturya Seferine Dair Bir Risale başlığıla kayıtlıdır. ${ }^{3}$ Sadece ağa bölüklerinin ihdası ve yeniçeri ağalarını gösteren kısım ise, Çorum Hasan Paşa Yazma Eser Kütüphanesi 3165/3 (varak 16b-18b) numarada Tarîh-i Ăga-i Yeniçeriyân-ı Dergâh-ı Âlî adıyla kayıtlıdır. Yeniçeri Teşrifat Mecmuası'nda ağalar Bektaş Ağa'ya (H.1051) kadar sıralanmışken, Esad Efendi nr. 3622'de Doğramacı Mehmed Ağa'ya (H.1112); Çorum Hasan Paşa Yazma Eser Kütüphanesi 3165/3'de ise Uzun İbrahim Ağa'ya (H.1076) kadar verilmiştir.

Yeniçeri Teşrifat Mecmuası, muhteviyatından ve bazı kısımlarında verilen tarihlerden anlaşıldığına göre 17. yüzyılın ortalarında yazılmıştır. Bazı ağalara yazlık ve kışlık elbise dağıtılması hususundaH.1054 (1644-45) yılı sayıları verilmiştir. Ocağatahsis edilen çayırlardan biçilen otların taksimini gösteren kısımdaH.1069 (1658-59) yılına aitmiktarlar gösterilmiştir. Padişahlara edilen dua metninde, en son merhum olarak Sultan İbrahim (1640-48) yâd edilmiş, IV. Mehmed (1648-1687) ise ismi zikredilmeden" padişahımız" olarak gösterilmiştir. Yeniçeri ağalarının isimlerinin verildiği son kısımda ise H.1051'e (1641-42) kadar görev yapan ağalar sayılmıştır. Mecmuada ismi geçen, yeniçeriler tarafından esir edildiği gösterilenMacar Zerinoğluise 9 Haziran 1664'te Kanije'ye üç saat mesafedeki Yeni Kale'de yapılan savaşlar sırasında mevcuttur. ${ }^{4}$

Tarihlendirmeyle alakalı diğer bir durum sadrazamla sefere giden yeniçeri ocağının alay tertibidir. Çünkü Yeniçeri Ocağı ilk defa 1594 yılında padişahtan ayrı olarak sadrazamla sefere gitmiş, bundan evvel sadece padişaha tabi olmuştur.

Mecmuanınilk ve en uzun kısmında; Sultan I. Süleyman'ın (1520-66) Beç Kralı (Habsburg İmparatoru) ile yaptı̆̆ 1 bir savaş sonrasında yeniçeri kışlalarının

\footnotetext{
${ }^{2} \mathrm{Bu}$ kısımları ihtiva eden nüsha yeni yazıya aktarılarak yayınlanmıştır. Osmanlı Kanunnâmeleri ve Hukukî Tahlilleri, IX, (haz. Ahmed Akgündüz), Osmanlı Araştırma Vakfı Yayınları, İstanbul 1994, s. 368-381. Fatma Kaytaz, "Osmanlı Askerî Teşkilatı Hakkında Bilinmeyen Bir Eser, Yeniçeri Ocağına İlişkin Bir Risale, (Değerlendirme ve Metin)”, Tarih Dergisi, Say1 57 (2013/1), İstanbul 2013, s. 4568 .

${ }^{3} \mathrm{Bu}$ risale Ayşe Pul tarafindan diğer bütün nüshalarla karşılaştırmalı olarak yayınlanmıştır. "Yeniçeri Teşkilatına Dair Bir Risale (Değerlendirme-Karşılaştırmalı Metin)” Belleten, Cilt: 84/Sayı: 301, Aralık 2020, s. 983-1044.

4 Erzurumlu Osman Dede, Köprülüzâde Ahmed Paşa Devrinde (1069-1080) Vukuatı Tarihi, Transkripsiyon ve Değerlendirme, (haz. Arslan Boyraz), Marmara Üniversitesi Türkiyat Araştırmaları Enstitüsü, Yayımlanmamış Yüksek Lisans Tezi, İstanbul 2002, s. 41.
} 
tamiri ve yedi kapı inşa edilmesi, su yolları ve çeşmelerinin yapılması, Etmeydanı'nıninşası ve tomruk denilen kasap dükkânlarının açılması anlatılmıştır. Yine bu sultan tarafindan Yeniçeri Ocağı'na yüz elli kese koyun akçesi bağlandığı; üç ayda bir her nefere 12 akçe yaka akçesiyle 30 akçe yay akçesi ve barut akçesi tayîn edildiği; meydanda bir mahzen inşa edilerek yağ, bal, pirinç ve mum verilmesi buyurulduğu; serhatlarda olan yeniçerilerlereise günde birer akçe nafaka akçesi, ayda bir kile kalburlanmış buğday ve iki adama bir okka et tahsis edildiği aktarılmıştır. $^{5}$

Kavânîn-i Yeniçeriyân, kışlaların tamiri hususunda mecmuadakilerle benzer bilgiler vermiştir. Ancak buradaki malumata göre kışlalara kapılar yapılmasıve ortasında mescit inşası Maktul İbrahim Paşa'nın fikri, padişahın müsaadesiyle olmuştur. İlk yapıldıklarında etrafı açık ve girilmesi kolay olan kışlalarda bazı ahlaksızlıklar olunca kapılar yapılmış, içeriye fahişe ve yabancı kimseleri sokmaması için kapıcılar görevlendirilmiştir. İbrahim Paşa, odalardaki inşa faaliyetleri bittiğinde ziyarete gitmiş, 21. ağa bölügü aşçısı tarafından kendisine şerbet ikram edilmiştir. Bu ikram karşıllğında "bu oda benim odam olsun" dediğinden burası paşa odası olarak anılmaya başlanmıştır. Orta mescidi daha sonra Sultan III. Murad (1574-95) zamanında büyütülerek cami şekline getirilmiş ve görevliler tayin edilmiştir. ${ }^{6}$

Yeniçeri Teşrifat Mecmuası'nın Kavânîn-i Yeniçeriyân'la uyumlu olduğu diğer bir husus, yeniçerilere et tayini ve bunun yapıldığı Etmeydanı'nın (Meydân-1 lahm) kurulmasıdır. Kavânîn-i Yeniçeriyân'a göre et kasaplardan orta aşçılarınca satın alınmaktayken II. Mehmed (1451-81), bir okka elli dirheminin 3 akçe üzerinden alacakları bir yer belirlemişti. Et fiyatlarındaki artışın yeniçerilere tesir

\footnotetext{
${ }^{5}$ Mecmuanın bu kısmına ait diğer nüshalarda ise birbirlerinden alınmış olduğundan olsa gerek daha farklı malumat verilmiştir: "Senede yüz elli kise akçe koyun akçesi ta ‘yîn idüb, be-her sene virilmesi içün hatt-1 hümâyûn ihsân buyurub ve yine üç ayda bir her nefere kırkar akçe yaka akçesi ve barut akçesi ve otuzar akçe kemân akçesi ta 'yîn idüb ve serhadlerde neferâta ve yamak yoldaşlara günde ikişer akçe nafakaların bir kîle kalburlanmış buğday ve iki âdeme bir vukıyye lahm ta "yîn buyurub" Yeniçeri Ocă̆ına İlişkin Bir Risale, vrk. 51a. Türk Tarih Kurumu Kütüphanesi'ndeki nüshada (Y/228) ise (4b-5a) bu kısım şöyledir. "Senede yüz elli kise akçe koyun akçesi ve üç ayda bir kere her bir nefere kırkar akçe yaka akçesi ve barut akçesi ve otuz akçe kemân akçesi içün hatt-1 hümâyûn ihsân buyurdılar ve serhadlerde mevcûd neferâta yamakâna yevmiyye ikişer akçe nafaka ve ayda birer kile halburlanmış buğday ve iki âdeme bir vukıyye lahm ta “yîn buyurub.”

${ }^{6}$ Osmanlı Kanunnâmeleri ve Hukukî Tahlilleri, IX, (haz. Ahmed Akgündüz), Osmanlı Araştırma Vakfi Yayınları, İstanbul 1994, s. 234-235.
} 
etmesine (zarâr-1 lahm) ${ }^{7}$ mâni olmak için bir vakıf kurmuş ve başına koyun eminini görevlendirmiştir. Zamanla düzen bozulmuş, Sultan I. Süleyman zamanında et verilmesi için senelik yüz elli kese koyun akçesi tayin edilmiştir. Aş̧̧ılar kasaplar önünde et almak için beklemekten şikâyet edince I. Süleyman Etmeydanı'nı tesis ederek tomruk denilen sekiz kasap dükkânı açtırmış, yeniçeriler etlerini buradan satın almıştır. Her tomruğa ikişer zimmi kasap ve dörder hizmetkâr görevlendirmiştir. ${ }^{8}$ Ancak meydanın tesisinin hikâyesinde adı geçen Gedik Ahmed Paşa, II. Mehmed devri devlet adamıdır. Zaten Kavânîn-i Yeniçeriyân'da Gedik Ahmed, ortasına kasaplardan et temin ederken zahmet çeken ve tebdil-i kıyafet gezen II. Mehmed'e muhtesip hakkında şikâyette bulunan, bu cesaretinden dolayı daha sonra muhtesipliğe tayin edilen aşçı olarak gösterilmiştir. ${ }^{9}$

Mecmuada ilk defa I. Süleyman tarafından ihdas edildiğinden bahsedilen tayinat ve tahsisatlar daha evvel mevcuttur. Ayrıcabunların miktarları hususunda verilen malumatlar dabazı bakımlardan kayıtlara uymamaktadır. Her üç ayda bir kere gösterilen yaka akçesi, senede bir kere taksim edilen çuhalarla beraber 12 akçe olarak verilmiştir. Yine yeniçerilere ok-yay temini ve tamiri için "yay akçesi" veya "keman-bahâ" adıyla yılda 30 akçe ödenmiş ancak barut akçesi verilmemiştir. Ortalara mirîden sadece mum verilmiş, diğer ihtiyaçlarını kendileri karşılamışlardır. Nafaka akçesi olarak kalelerdeki nöbetçi yeniçerilere günde bir akçe ödenmişti ancak bu ödeme 17. yüzyılın başında kaldırılmıştır. Günlük bir çift ekmek karşlığında verilen buğday miktarı ise sadece Bağdat'ta bir kile, diğer kalelerde yarım kileydi. İki kişiye bir okka et tayinatına da kayıtlarda rastlanmamıştır. Yaka akçesi malumatındaki uyumsuzluk, mecmuanın yazıldığ zaman bu ödemenin yay akçesi gibi kalkmış olmasıyla alakalı olmalıdır. ${ }^{10}$

\footnotetext{
7 "Yeniçeri meydanı derler odalar yanında bir yer vardır. Anda beğlikden koyun emini et getürür ve kıyyesi üç akçeye alurlar. Bir yılda ne kadar zarar olursa eksiğün mîrî tarafindan verirler, Yeniçerilerin zarar-ı lahm dedikleri budur." "Sadrıâzam Kemankeş Kara Mustafa Paşa Layihası", (haz. Faik Reşit Unat), Tarih Vesikaları, Nisan 1942, I/ 6, 456.

${ }^{8}$ Kavânîn-i Yeniçeriyân, 199-200. Yeniçeri Ocağına İlişkin Bir Risale, Süleymaniye Kütüphanesi, Esad Efendi, nr. 3622, vrk. 50b, 53b. Yeniçeri Teşrifat Mecmuası, vrk. 3 ab.

${ }^{9}$ Kavânîn-i Yeniçeriyân, 200.

${ }^{10} \mathrm{Bu}$ hususlar için bkz. İsmail Hakkı Uzunçarşı1l, Kapıkulu Ocakları, I;Abdulkasim Gül, 18. Yüzyılda Yeniçeri Teşkilatı, Atatürk Üniversitesi Türkiyat Araştırmaları Enstitüsü, Yayımlanmamış Doktora Tezi Erzurum 2020.
} 
Mecmuada gösterilen, yeniçerilerden 1500'ünün korucu yahut 500'ünün korucu, 500'ünün oturak yapılmas $1^{11}$ ise I. Süleyman zamanında olmadığ1 kayıtlardan kolaylıkla anlaşılacak bir durumdur. Ayrıca koruculuk ve oturaklığın I. Süleyman zamanında farklı uygulamaları vardır. Bu padişah devrinde korucuların sayıları çok az (1549 yılında 15) ve yevmiyeler çok düşüktür. Emeklilik ise yeniçerilikten çıkarılma şeklinde uygulanmıştır. Türk Tarih Kurumu Kütüphanesi'ndeki risalede bahsedilen 29 akçeyle koruculuk ise 17. yüzyılın ortasına doğru çıkmıştır. ${ }^{12}$

Yine mecmuada, talimhanenin ilk kuruluşunun, ok ve tüfek taliminden mesul bir talimhaneci tayin edilmesinin I. Süleyman zamanında olduğu yazılmıştır. Ancak I. Süleyman'dan evvel talimhane mevcuttu. Muhtemelen bir yer değişikliği veya büyütmeyi kasteden Kavânîn-i Yeniçeriyân'a göre talimhane II. Bayezid (1481-1512) devrinde bina edilmiş ve burada talim yapılan beş yer yapılmıştır. Ayrıca bu kaynakta, yeniçerilerin itirazlarına rağmen I. Selim'in ok atmada mahir İran tarafından gelmiş birini talimhaneci yaptığı anlatılmıştır. ${ }^{13}$

Yeniçeri Ocağı cemaatler ve sekbanlardan oluşurken II. Bayezid zamanında altmış bir ağa bölüğü ilave edilmiş, ayrıca ocağın içinden yükselerek gelen yeniçeri ağaları saraydaki yüksek rütbeli ağalardan seçilmeye başlanmıştır. ${ }^{14}$ Mecmuada bu değişiklik için I. Selim'in saltanatına denk gelen 8 Ağustos 1515 tarihi verilmiş, ağalardan H.1051 tarihine kadar görev yapanlarsıralanmıştır. Ancak yeniçeri ağalarının isimlerinin verildiği kısımda, bütün ağaları ihtiva etmeme bakımından eksiklik; görev tarihleri, sıralamaları ve önceki rütbeleri bakımlarından çok fazla hata mevcuttur. ${ }^{15}$ Ağalarla ilgili diğer hatalı husus, ocak içinden tayin edilenler hakkında kayıtlara uymayan malumatlar olmasıdır. ${ }^{16}$

\footnotetext{
11 İncelediğimiz nüshada 1.500 serdengeçtiye koruculuk verildiği yazılıdır. Diğer iki nüshada ise emeklilik verildiği yazılmıştır.

${ }^{12} \mathrm{Bu}$ husus için Gül, 18. Yüzyılda Yeniçeri Teşkilatı, üçüncü bölüme bakınız.

${ }^{13}$ Kavânîn-i Yeniçeriyân, 236.

${ }^{14}$ Gül, 18. Yüzyılda Yeniçeri Teşkilatı, 7.

${ }^{15}$ Karşılatırma yapılması için bazı ağa tayinleri burada verilmiştir: H.953'ten 960'a kadar yeniçeri ağası Pertev Ağa iken bu tarihte kapıcucbaşı Ferhat Ağa tayin olmuş, ama kısa süre sonra azledilmiş ve başkapıcı Ahmed Ağa tayin edilmişti. H.971 yılında Hasan Ağa'nın yerine gelen Ali Ağa, H.975'de azledilmiş ve yerine Sinan Ağa, ağa olmuştu. Sinan Ağa, H.976 sonunda azl, yerine kapıcıbaşı Cafer Ağa tayin olmuştu. H.977 yılında Cafer Ağa yerine başkapıcı Siyavuş Ağa gelmişti. H.979 Şaban ortasında Siyavuş Ağa Rumelibeylerbeyi yapılınca kapıcıbaşı Mustafa Ağa yeniçeri ağası olmuştu. 983 Safer'in 4. günü Mustafa Ağa Kastamonu sancakbeyi, yerine Ciğalazade Sinan Ağa yeniçeri ağası olmuştu. Sinan Ağa 986 yılı ortalarına kadar görev yapmış, sonra başmirahur Mehmed Ağa tayin edilmişti. H.991 Ramazan'ında Yusuf Ağa Budin beylerbeyi olunca yerine
} 
Mecmuanın birinci kısmının I. Süleyman devrini esas almasının sebebi, ocağın kuruluşu ve gelişimi hakkındaki bilgilerin zamanla tahribata uğramasıdır. Kavânîn-i Yeniçeriyân ve Telhîsü'l-beyân fi Kavânîn-i Âli Osmân gibi ocağın tarihini gösteren eserlere rağmen artık kuruluş zamanı olarak Sultan Süleyman devri olduğu zihinlerde yer etmeye başlamıştır. Zaten bu kanaat zamanla daha güçlenerek 18. yüzyılda genel bilgi halini almıştı. Sultan III. Ahmed (1703-30) devrindeki resmî kayıtlarda bile yeniçeriliğin esaslarının Sultan Süleyman devrinde tesis edildiği gösterilmiştir. ${ }^{17}$ Yine bir sekbanbaşı tarafindan yazılan Koca Sekbanbaşı Risalesi'nde ocağın bu padişah döneminde teşekkül ettiğinden bahsedilmiştir. ${ }^{18}$

Bunda en mühim amil, ocak mevcudunun I. Süleyman'dan sonra artmas1, nefer alımında usul değişikliğinin olması ve emeklilik gibi ocak işleyişine oldukça tesir eden bazı uygulamaların ortaya çıkmasıdır. Çünkü bütün bu değişiklikler bozulmanın emareleri olarak değerlendirilmiştir. Mecmuada zaten bazı değişiklikler, eski uygulamalar gösterilerek zımnen tenkit edilmiştir. Mesela 1600'lere kadar yeniçeri oğulları genel olarak Acemi Ocağı'na alınarak akabinde yeniçeri yapılırken bu tarihten sonra acemi oğlanlığı çağına yeni gelmiş olanlar bile doğrudan yeniçeri yapılmıştır. Mecmuada, Sultan I. Süleyman'ın “kuloğulları yirmi üçer yaşına girmeyince be-dergâh ${ }^{19}$ itmeyeler." diye fermanı olduğu

mirahur Mehmed Ağa gelmişti. 10 Şevval 992'de Mehmed Ağa Rumili beylerbeyi, silahdar Halil Ağa yeniçeri ağası olmuştu. Selhi Rebiülahir 999'da Hasan Ağa yerine mirahur Mehmed ağa tayin edilmişti. Mehmed Ağa Cemaziyelahir 1000'de azledilmiş yerine silahdar Halil Ağa gelmişti. Şevval 1000 tarihinde azledilen Halil Ağa'nın yerine kapıcıbaşı Mehmed Ağa yeniçeri ağası olmuştu. 1002 Zilhicce'de azledilen Mehmed Ağa yerine Yemişçi Hasan Ağa, 3 Cemaziyelevvel 1004'te kapıcıbaşı Veli Ağa yeniçeri ağası tayin edilmişti. 11 Receb 1011'de Bostancıbaşı Ferhad Ağa ağa olmuştu. Ferhat Ağa 28 Zilkade 1011'de Anadolu beylerbeyi olunca büyük mirahur Kasım Ağa, ağa yapılmıştı. Gurre-i Cemaziyelevvel 1012'de kapıcıbaşı Ahmed Ağa yeniçeri ağası olmuştu. 29 Ramazan 1025 'de şehit olan Mustafa Ağa yerine kapıcıbaşı Ahmed Ağa tayin edilmişti. Seyyid Lokman, Tomar-ı Hümayûn, Topkap1 Sarayı Müzesi Kütüphanesi, Hazine nr. 1321, Görüntü No 7485-86, 7488, 7492-94, 7499-7501, 7505. Selânikî Mustafa Efendi, Tarih-i Selânikî, I, (haz. Mehmet İpşirli), TTK Basımevi, Ankara 1999, s. 77, 150, 202, 215, 220, 231, 265, 278, 384. BOA, KK. d. 244, s. 118. BOA, A.NŞT. d. 1140, s. 125. BOA, MAD.d. 18155, s. 101, 129, 151. BOA, A.RSK. d,1484, s. 181.

${ }^{16}$ Bu husus için bkz. Gül, 18. Yüzyılda Yeniçeri Teşkilatı, ikinci bölüm.

${ }^{17}$ III. Ahmed'in Hatt-ı Hümâyûn Mecmuası, (İstanbul Üniversitesi Kütüphanesi, TY, nr.6094, vrk. Ib30a), (haz. Muhammed Dervişoğlu), İstanbul Üniversitesi Edebiyat Fakültesi Mezuniyet Tezi, İstanbul 1974, İstanbul Üniversitesi Kütüphanesi, no 10506, 1-2.

${ }^{18}$ Koca Sekbanbaşı Risalesi, haz. Abdullah Uçman, Tercüman 1001 Temel Eser, Tarihsiz, 4246-47. Assm Efendi Tarihi, I, (haz. Ziya Yılmazer), TYEKB Yayınları, İstanbul 2015, 643.

19 Karşılı̆̆ı "kapıya çıkma" olan "be-dergâh", acemi oğlanları ve yeniçeri oğullarının Yeniçeri Ocă̆ı'na yazılması demektir. 
aktarılarak değişikliğin münasip olmadığı izah edilmiştir. Özellikle 1590'lardan itibaren ocağa girmenin kolaylaşması, zaten gittikçe azalan devşirmenin 1640'lardan sonra Yeniçeri Ocağı için yapılmaması tenkit edilerek Sultan I. Süleyman'ın “kuloğulları ve devşirme ocak ağaların hidmetlerinde olup pişmiş kâl olmuş 'ankâlarından, kat'a ki el 'iyâzübillâh Urus ve 'Acem ve Cingâne ve Türk re'ayâsının evlâdların ve sâir mahlûkun evlâdların, Harputlu ve Diyarbakırlı ve Malatyall olmaya." diye ferman yazdırdığı ve "Bu yukaruda ta'yîn ve tasrîh olunanlardan gayri âdemı ya rüsvetle veya rica ile veya bir büyük yerden şefâ 'at ile be-dergâh idüb hâlis kullarımın aralarında bir ecnebî korlarsa Allah 'Azîmüşşânın ve yüz yirmi dört bin peygamberlerin la'netleri ol zâbitlerin üzerlerine olsun" dediği gösterilmiştir. Bahsedilen durum solaklık için de geçerliydi. Padişahın hususi muhafızları olan solaklar tecrübeli ve yararlı1ık gösteren yeniçerilerden seçilmişken 17 . yüzyılın ortasından itibaren bazen acemi oğlanlarından daha çok ise solakların oğullarındanseçilmişti. Mecmuada bu değişim, "Uzun boylu ve kiyâfetlü âdemlere verilür idi ve genç ve biyuklı" âdemlere verilmezdü. Ekseri umûr-dîde iş görmüs ve kal'a fethin bilür ve metris ahvâlin bilür odabaşılara verilür idi. Ve odabaşıların doğru yolları solaklıdır, meğer kim ziyâde ihtiyâr ve 'amel-mânde bir odabaşlya etmek verilürdi. Solakllk mahlûl oldukda yeniçeri ăgası telhîs itmedikçe verilmez idi." ifadeleriyle anlatılmıştır.

${ }^{20}$ Bıyıklı olmak genç manasında kullanılmıştır. Yeniçerilerden sadece emektar, eskiler ve ağalar sakal birakabilirdi. 


\section{Yeniçeri Teșrifat Mecmuası Metni}

\section{Bismihu Subhânehu ve Te‘âlâ}

Sultân Süleyman Gāzîi ${ }^{21}$ cennet-mekân firdevs-âşiyân merhûm ve mağfûrun-leh Sultân Süleyman hazretleri Beç Kralı üzerine altı def'a sefer idüb hikmet-i Hüdâ fethi müyesser olmayub yedinci def'a mükemmel asker-i İslâmla tekrar gitdikde yedi krallar bir olub öyle ahd u yemîn ederki Osmanlı'yı ara yerden kalduralar. Azîm tavr u dînidüb ve tedârikler iderler. Bu tarafdan merhûm Sultân Süleyman sa'âdetle azîmet idüb mahalline vardıklarında yedi krallar ile mukābil olduklarında küffâr-1 hâksârın ziyâde galebesinden cümle beglerbegiler bozulmak sadedinde iken merhûm Sultân Süleyman gördükim iş gayrî türlü oluyor, sancağ-1 şerîfi ve İmâm-1 a'zam hazretlerinin sancăg-1 şerîfin kulkethüdâsı Yavuz Selim Ağa'ya ve başçavuş Murtazâ Ağa'ya ve başyayabaşı Deli Hamza Ağa'ya teslîm idüb, buyurur ki; "Kullarım bugün, Kerbelâ günümüzdür, bugünden sonra bize ve sizlere dirlik harâmdır, İslâm gayretin elden komak sizlere lâyık değildir, Peygamber Aleyhi's-salâtu ve's-selâmın sancağ-1 şerîfi ve İmâm-1 a'zam hazretlerinin sancağ-1 şerîfinden hicâb eylen, yarın bunların sâhiplerinden şefâ 'at istersiz" deyu buyurduklarında cümle Yeniçeri Ocağı'nın halkı bu sözleri istimâ‘ eylediklerinde cümlesi hayâtların terk idüb bin beş yüz serdengeçdi gāzîleri ile başyayabaşı Deli Hamza Ağa'ya emânet vaz'idüb bir uğurdan kendülerin küffâr-1 hâksâra urub hücûm eylediklerinde yedi gün ve yedi gice asla ârâm olunmayub dost ve düşmen fark (1a) olunmayub bir ceng-i 'azîm olub sekizinci gün sabâh namâzından sonra emr-i Hâk ile küffâr bir mikdâr bozulmağa yüz duttukda cümle beglerbegiler tâze cân bulub ve her tarafdan İslâm 'askeri yürüyüb küffâr-1 hâksâr1 bölük bölük itdiklerinde 'azîmetlü pâdişâhın karârı kalmayub ve solakbaşların ellerinden bir vechile halâs olub sûret-i tebdîl ile silâhdâr ve çukadâr ve rikabdâr ve dülbend ağasıyla cenge girüb vâfir küffârları katl iderken solakbaşıların 'akılları başlarından gidüb dört solakbaşılar ve dört kethüdâlar ve dört odabaşılar cenge girüb gāzî hünkârı bulub cengden çıkardıklarında bizzât kendileri kullarına istimâletler virüb; “Kullarım bugün mü'mînlerin ulu bayramlarıdır, bu bayram bir dahi ele girmez, feth [ü] ${ }^{22}$ nüsret bizimdir, sizlere müjde olsun kullarım" deyu buyurduklarından silâhdâr ağalığından gelme Rüstem Ağa yeniçeri ağası ve

\footnotetext{
${ }^{21}$ Koyu şekilde yazılan yerler, metinde konunun başlıkları olarak kırmızı mürekkeple yazılan kisımlardır.

${ }^{22}$ Metinde "feth nüsret" şeklinde yazılıdır.
} 
kulkethüdâsı Yavuz Selim Ağa ve başyayabaşı Deli Hamza Ağa ve başçavuş Murtazâ Ağa sancağ-1 şerîfleri alub gāzî hünkâra getürüb teslîm idüb ve cevâb iderler ki; "Sa'âdetlü hünkârım dîn-i mübîn yolunda ve sa'âdetlü hünkârımın uğruna cânımız fedâdır, kullarını hayr du âdan unutma" didiklerinde gāzî hünkâr ağlayub vâfir hayr du'âdan sonra sancağ-1 şerîfleri bekleyen bin beş yüz serdengeçdi gāzîlerinin karârları kalmayub cenge girmişlerdir. Bir tarafa yeniçeri ağası gidüb ve bir tarafa kulkethüdâsı ve başçavuş gidüb ve hikmet-i Hüdâ yeniçeri ağası gitdügi tarafda Dubrovenedik kralı bulunub yeniçeri ağasıyla bir hayli ceng ü cidâldan sonra kral olduğun bilmeyüb başın kesüb huzûr-1 humâyûna getürdi ve kulkethüdâsı ve başçavuş sancağ-1 şerîfleri bekleyen bin beş yüz serdengeçdi gāzîleri ile (1b)düşdükleri tarafta Zerinoğulları ve Paykanoğulları itmişler ${ }^{23}$ iki gün ve iki gice aç ve susuz 'azîm cenglerden sonra firsatı Hak ta'âlâ kulkethüdâsı ve başçavuş ve bin beşyüz serdengeçdi gāzîlerine virüb iki melâ‘înleri dutub ve esîr idüb huzûr-1 hümâyûna getürmişlerdir. Ve cümle yeniçeri gāzîleri dahi yedi gün ve yedi gice aç ve susuz asla ârâm ve kârar olunmayub onar onarölüb dîn uğruna cânların fedâ idüb kendülerin ol bi-pâyân küffâr-1 hâksâr 'askerine urub cân u gönülden hücûm eylediklerinde öyle bir ceng eylemişlerdir ki dünyâ duralı ne olmuş ve ne olacakdır. Ertesi gün sabâh namâzından sonra yedi kralların cümlesi bozulub karâr-1 firâra tebdîl eyledüklerinde bu ahvâli gāzî hünkâr müşâhede eyledikde atından yere nüzûl idüb mübârek yüzün toprağa sürüb şükr-ü Yezdân eyleyüb tekrâr atına süvâr olub sipâhîler ağası ve silâhdâr ağası bu ahvâli gördüklerinde dört aşağı bölük ağaların hünkârın yanlarında alıkoyub kendüleri cenge girdiklerinde küffârın dip alaylarına uğrayub ceng ü cidâl iderek küffâr bozulub cümle topların ve cebehânelerin zabt idüb sipâhîler ağası Handân Ağa gelüb gāzî hünkâra müjde eyleyüb mensûr ve muzaffer gelüb yerinde karâr eylediklerinde hünkârın yanında olan dört aşağı bölük ağaları hünkârın huzûr-1 şerîflerine gelüb feryâd eylediler kim; "Hünkârım bu dört bölük fukarâ kullârın bu büyük gazâdan mahrûm kaldık" dediklerinde gāzî hünkâr bunların feryâdların gördükde Rumili beylerbegisi İslam Paşa'yı ser'asker idüb ve Anadolu beylerbegisi Zülfikâr Paşa'yı ve Sivas beylerbegisi Arslan Paşa'yı dört aşağı bölük ağaların ma'an ta'yîn idüb firâr iden küffârın ardına revâne oldular. Sürûr ile küffâra irişüb (2a) cümlesin kırub on bin iki yüz kelle ve üç bin dil alub ganîmet-i mâl ile huzûr-1 hümâyûna getirmişlerdir. Bu ceng-i kübrâda yigirminci cemâ‘atin

\footnotetext{
${ }^{23}$ Cümlede eksiklik vardır. Diğer nüshadalarda "rast gelüp” ifadesi mevcuttur.
} 
yoldaşı Deli Mendereci ${ }^{24}$ ve otuz dört bölügün Mustafa Üsküblü ve otuz iki bölügün Rıdvan Beşe ve otuz beş bölügün Deli Ali Avlonyal1 ${ }^{25}$ ve otuz üç bölügün Deli İvaz ve onuncu bölügün Deli ${ }^{26}$ Baba ve on beş bölügün Deli Hamza Pirlepeli ve on dört bölügün Deli Kurt Belgradlı bu zikr olunan yedi ${ }^{27}$ nefer yoldaşlar hemcivârlar olmağla birbirlerine kafadâr ve hevâdâr olub bu cengde ziyâde yüzaklıkları idüb herbiri üçer dörder dil ve baş alub gāzî hünkâra gelürken hikmet-i Hüdâ Orta Macar ve Küçük Macar krallarına rast gelüb gāzîler bunları gördükde hayâtlarından nâ-ümîd olup kendülerin küffâr askerine urub küffâr askeri dahi bunlara hücûm eylediklerinde gāzîler dahi bir uğurdan tekbîr getürüb yürüdüklerinde Allah 'azîmüş-şân firsatı gāzîlere virüb küffârı bozub ve iki kralları esir idüb huzûr-1 hümâyûna bu kadar dil ve baş ile geldiklerinde gāzî hünkâr ayağ üzere kalkub mübârek yüzün toprağa sürüp gözlerinden yaş yerine kan akıdub; "Kullarım gazânız mübârek olsun Hak Te'âlâ cümlenizin dest-gîrîolsun" deyu vâfir hayr u du'âdan sonra gāzîlere birer hil'at-1 fâhireler ihsân ve bir kise altun in ‘âm itdikde mezbûr gāzîler hünkârın in'âmın kabul itmeyüb boyun burub huzûr-1 şerîflerinde durduklarında gāzî hünkâr; "Kullarım niçün ihsânım kabul itmediniz, murâdınız nedir" deyu buyurduklarında cevâb verdiler ki; "Hünkârım ihsânına her bâr muhtacız ve lâkin sa'âdetlü hünkârımızdan murâdımız vardır," "Nedir kullarım" deyu buyurduklarında "Hünkârım İstanbul'da odalarımızda (2b) suyumuz yokdur azîm zahmetler çekilür bir iki masurasucağız ricâ ederiz hünkârımızdan" deyü cevâb virdiklerinde "Olsun kullarım" deyu iki masura su içün hatt-1 hümâyûn ihsân idüb buyurdu ki; "Kullarım İnşallahu Te'âlâ Âsitâne’ye varduğumuzda cümle kullarımı suya doyum ideyim" deyü 'ahd ü yemîn ider. Bundan sonra düşmen bertaraf olub sürûr ve safâ ile sa'âdetle Asitâne'ye gelüb kırk gün ve kırk gice ales-seviye azîm donanmalar olub herkes karâr-dâde olduklarında sa'âdetlü hünkâr eski saraya teşrîf buyurub altı bölük ağalarına ve kethüdâlarına ve Yeniçeri Ocağı halkına ve yeniçeri kullarına azîm ziyâfet idüb ziyâfetten sonra altun ile çil akçe harman misâl yiğdırub ve birbirlerine karuşdurub altun tepsi ile kulların başlarına nisâr idüb cümle vüzerâya kürkler giydürüb ve sipâh ağalarına ve kethüdâlarına azîm hil'atlar ihsân idüb yeniçeri ağasına ve

\footnotetext{
${ }^{24}$ Kelime Mandaracı okunacak şekilde yazılmıştır. Bu nüshanın başka bir yeri ve diğer nüshada ise Mendereci şeklinde yazılmıştır. Bu yüzden Mendereci yazılışı tercih edilmiştir.

${ }^{25}$ Diğer nüshalarda Alasonyalı olarak yazılmıştır.

${ }^{26}$ Dğer nüshalarda Veli olarak yazılmıştır.

${ }^{27}$ Yedi nefer denilmiş ancak metinde sekiz kişinin ismi sayılmıştır. Diğer nüshada Mustafa Üsküblü yazılmamıştır
} 
kulkethüdâsına ve başçavuş ve sâir ocak halkına fâhir hil'atlar ihsân buyurub ve beher sene Yeniçeri Ocă̆ı'na yüz elli kise koyun akçesi ta'yîn idüb beher sene virilmek içün hatt- hümâyûn ihsân idüb ve üç ayda bir her nefere on iki akçe yaka akçesi ve otuz akçe yay akçesi ve barut akçesi ta'yîn idüb ve serhadlarda olan nefarât yoldaşlara günde birer akçe nafaka akçesi ta'yîn ve ayda bir kile kalburlanmış buğday ve iki adama bir vukiyye lahm ta'yîn buyurub ve bundan mâ‘adâ bin beş yüz umur-dîde ihtiyâra koruculuk ihsân buyurub kānûn buyurdular ki pâdişâhlar sefere gitdükde bu nice beş yüz umûr-dîde korucu ve beş yüz umûrdîde oturaklar ma'an sefere gidüb bu korucu oturaklar cenge girmeyüb çadırda bekçi olub (3a) bir kal'a muhâsara olub alınmak mümkün olmadığı sûretde cengden âzâdlu kullarum ile müşâvere eylemek bu kal'anın fethi ne vechîle olur deyu bu zikr olunan umûr-dîde ihtiyarlar bir yere gelüb müşâvere eylediklerinde anların re'yi ve tedbîrleri üzere kal'anın fethi müyesser olurdu. Ve yukarıda zikr olunan ziyâfetlerden sonra sa'âdetlü gāzî hünkâr odalara gelüb odaları ta'mîr idüb cümle karizlerin mustahkem kargir yapdurub ve bed yerlerde kullarum sudan zarûret çekmesun içün çeşmeler yapdurub ve meremmât lazım geldikde şehremîni üzerine ta 'yîn buyurub merammâta harc u sarf olunan akçe mîrîden virilmek üzere hatt-1 hümâyûn ihsân idüb ve odalarda yedi kapu yapdırub her kapuda birer bekçi ta'yîn buyurub ve birer vukiyye lahm ihsân idüb ve buyururlar ki; "Oda kapularından içerü kullarımdan gayri ecnebî kimse komayasız ve avretten ve taze oğlandan bir kimesnenin girdügüne rızây-1 hümâyûnum yokdur meğer ki kuloğulları ola. Ve babasından yetim kalan kuloğullarını odalarına alub hizmet itdüreler, taze olduğu sûretde yatsu namâzından sonra oda kethüdâsı ol kuloğlın bir tenhâ odanın içine koyub üzerine kilidleye ve sabâh oldukda oda kethüdâsı kapuyu açub yine hidmetine meşgûl ola. Ve mezbûr kuloğulların bir ma'kûle bir kabâhat zuhûr eder ise odabaşısı ve vekilharcı ta'zîr itmeyüb yine oda kethüdâsı ta'zîr ede kat'a kim otuz dokuz değnekden ziyâde urmaya. Ve mezbûr kuloğulları yirmi üçer yaşına girmeyince be-dergâh itmeyeler ve kuloğulları ve devşirme ocak ağaların hidmetlerinde olup pişmiş kâl olmuş ankālarından, kat'a ki el'iyâzübillâh Urus ve Acem ve Cingâne ve Türkre'ayâsının evlâdların (3b) ve sâir mahlûkun evlâdların, Harputlu ve Diyarbekirli ve Maladyalı olmaya. Bu yukaruda ta'yîn ve tasrîh olunanlardan gayri âdemi ya rüşvetle veya ricâ ile veya bir büyük yerden şefâ'at ile be-dergâh idüb hâlis kullarımın aralarında bir ecnebî korlarsa Allah Azîmüş-şânın ve yüz yirmi dört bin peygamberlerin la'netleri ol zâbitlerin üzerlerine olsun, ta'yîn ve tasrîh olunan tâ'ifeden gayri kimseyi hârem-i hâsımda be-dergâh iderlerse 
ocağımın hâkimleri sû-ihâtimeye mübtelâ olub dünyâ ve âhiretleri harâb ola" deyü la“netnâme yazılmışdır. "Bir şehirlü âdam girdügüne rızâm yokdur" deyu muhkem tenbîhden sonra yedi kapularına çatal zencir yapdırub lâzım geldikde açub yine kapayalar ve bâlâda mestûr olan gāzî yoldaşları gāzî hünkâr huzûr-1 şerîflerine da'vet buyurub; "Kullarum benim ile bir büyük gazâda bulundunuz. Elhamdulillâh-i Te‘âlâ yuvamıza gelüb dâhil olduk. Berhurdâr olun, yüzünüz ak olsun, odalarınız ta “mîr ve suyunuz vâfir, hâtırınız hôş oldu mu" deyu buyurduklarında mezbûr gāzîler cevâb verdiler ki; "Hünkârım Hak Te'âlâ 'ömrünü uzun eyleye. Hâtırımız hôş fe-emmâ ki bu sudan bu kullarınıza fâ'ide olmadı ve bu binâ buyurduğun havza ancak kifâyet eder. Kulların murâdları odamızın önünde olmak üzere hatt-1 hümâyûn ihsân buyurmuşdunuz, va'deye hilâf eylemez ${ }^{28}$, pâdişâhların va'desi va'de gerekdir didiklerinde gāzî hünkâr gülüb; "Kanı sizlere verdiğim hatt-1 hümâyûnumu getürün” deyu buyurduklarında yigirminci cemâ‘atin yoldaşı Deli Mendereci hatt-1 hümâyûnu gāzî hünkârın eline virdükde tekrar gülüb ve iki masura su dahi ilhâk idüb ve birer çeşme ol gāzîlerin hâtırları içün odaların önünde (4a) yapdırub ve tenbîh buyurur ki; "Musluklarınız doldukda gene havza aksun" deyu ziyâde tenbîh buyururlar ve yigirmincinin bir yoldaşın mezbûr havza bekçi ta 'yîn idüb ve günde bir vukiyye lahm ihsân buyurub ve sefere gitmekden mu'âf eder. Bu minvâl üzere bir la'netnâme yazmışdır ki; "Eğer binâ eyledigim havzları ibdâl ve ta'yîn eyledügüm suyun eksik iderlerse Allah Azîmüşşânın ve yüz yirmi dört bin peygamberlerin ve cem'-i melâike ve ins ve cinnin la'neti anların üzerine olsun" deyu la'netnâme yazdırub ve üzerlerine kulkethüdâsın nâzır ta'yîn buyurub ve bu ahidnâme yazub kulkethüdâsının eline virmişdir. Ve odalar ta'mîr olub ve suyolları ve karizler ve havzlar tamam oldukda gāzî hünkâr meydâna gelüb ta'lîmhâneyi yapdurub ve üzerine ta 'lîmhânecibaşıyı nâzır ta'yîn idüb tüfenk atan yoldaşlara ve kemânkeşlere ok atmă̆ ta'lîm itmek içün ve ta'lîmhânecibaşıyı sefere gitmekden ve serhadlara alıkonulmakdan mu'âf buyurub bütün gün başında yusufî ile durub tüfenk atanlara ve solaklara ve sâir kemânkeşlere ta'lîm itmeğe me'mûrdur ve pâdişâh sefere gitdikde ta'lîmhânecibaş1 bile gitmeğe me'mûrdur. Ve bundan sonra tüfenk atılacak mahalle yonma daşdan kâkir dıvar yapdırub ve orta yerinde somaki mermerden nişângâh yapdırub ve metris içün somaki miller dökdirüb ve bu millerin ardında yonmadaşdan bir büyük sofa yapdurub kendüleri sa'âdetle otumağiçün ve yanında bir çeşme binâ idüb ve kulları tüfenk atdıklarında sudan zarûret çekmemek içün beher sene gāzî hünkâr

\footnotetext{
${ }^{28}$ Diğer nüshalarda "padişahlar va“deye hilâf eylemez" ifadesi bulunmaktadır.
} 
meydâna gelüb kullarının tüfenk atdıkların seyrederdi ve nişânı uran kullarına 'azîm ihsânlar iderdi. Ba'zı nişânı uran kullarının (4b) kimine bir dülbend ve kimine bir yay ve kimine bir çıkın akçe ihsân iderdi. Gāzî hünkâr bir gün meydâna gelüb tüfenk atdırmak içün gelürken odaların ağakapusundan içerü girüb yeniçeri ağası rikâbında yürürken odaların keçeciler mahalline geldikde bir köpeğe rast gelüb sa'âdetle at başın çeküb kulkethüdâsın huzûruna da'vet idüb buyurdu ki; "Ben seni odaların üzerine nâzır ta'yîn eyledim, benim harem-i hâsımın niçün köpek korusun" deyü ziyâde azar idüb ve kapucuyu öldürmek murâd eyledikde yeniçeri ağası ricâ idüb cânın halâs idüb ve lâkin mezbûru merd-i timâr idüb eline bir berât virüb ol kapucuyı ocakdan ihrâc ider.Ve ba'de meydâna gelüb sa'âdetle yerinde karâr eyledikde tüfenk atmak lâzım geldikde evvel saksoncubaşı saksonları getürüb ayuya salıvirüb pareletdirdi. Ba'de pehlivanlar gelüb güreş olurdı ve her odalarda birer ikişer pehlivanlar olmak kānûndur. Ve ba'de gürzler salarlardı ve ba'de solaklar ve sâir kemânkeşler gelüb hünerler gösterirlerdi. Ve ba'de ocak ağaları ve kulkethüdâsı, başçavuş ve cümle zabitân tertîb üzere gāzî hünkârın huzûrunda durub başlarında yusufî giyerlerdi. Evvel yeniçeri ağası yer öpüp tüfenkçileri dolu tüfengi hâzır idüb eline virüb atard1, andan sekbânbaşı andan kulkethüdâsı andan zağarcıbaşı andan saksoncubaşı andan turnacıbaşı andan dört hâseki andan başçavuş gāzî hünkârın huzûrunda tertîb üzere nişâna kurşun atarlardıve ba'de başçavuş birinci devecilerden başlayub bölük bölük çă̆ırub çorbacıların başlarında yusufî neferâtıyla hünkârın huzûrunda nişâna tüfenk atarlardı. Nişânı (5a) uran yoldaşlara 'azîm ihsânlar iderdi. Cemâ'atlar ve bölükler tamam oldukda segirdim olan odaların aşçıları hâzır olub ve soyunub segirdim ile et kaparlardı. Ziyâde segirden aşçıya solaklık mahlûl oldukda ana ihsân ve olur olmaz âdeme solaklık virilmezdi. Uzun boylu ve kiyâfetlü âdemlere verilür idive genç ve bıyuklı âdemlere virilmezdü. Ekseri umûr-dîde iş görmüş ve kal'a fethin bilür ve metris ahvâlin bilür odabaşılara virilür idi. Ve odabaşıların doğru yolları solaklıkdır, meğer kim ziyâde ihtiyâr ve 'amel-mânde bir odabaşıya etmek virilürdi. Birodanın çorbacısı mahlûl oldukda solak olan odabaşılara virilür idi. Solaklık mahlûl oldukda yeniçeri ağası telhîs itmedikçe virilmez idi ve bir seferde çorbacı şehîd oldukda solaklara virilürdi. Ecnebîye ve nefere çorbacılık virilmemek içün sa‘âdetlü azametlü Sultân Süleyman Han Gāzî rahmetüllâhı aleyh la'netnâme yazmışdır. Ve herkes solakbaşı olmaz idi, solak bir ulu mertebedir gayetle ma'kûl söz bilür, gayetle umûr-dîde ve her ahvâle vâkıf ve pâdişâhların sözün anlar âdemler solakbaşı olur idi. Ve cenglerde pâdişâhları zabt idüb ceng 
ahvâlin pâdişâhlara i'lâm iden ve ceng mahallinde pâdişâhları bir yavaş ata bindürüb ve bindügü ata pazbend ${ }^{29}$ uran solakbaşıdır. Ve ceng mahallinde dört solakbaşı ve dört kethüdâlar ve dört odabaşılar sa'âdetlü hünkârın eteklerine muhkem yapuşub ve dört yüz kemânkeş solaklar hünkârın dört etrafin kuşadub dururlar, silâhdârı ve çukadârı ve rikâbdârı (5b) ve dülbend ağasın hünkârın yanında komazlar, solakların ardlarında iç halkı top olub dururlar ve ceng mahallinde sa'âdetlü ve azametlü ve şevketlü pâdişâh-1 âlempenâh hazretlerini ve vezîr-i a'zam hazretlerini yeniçeriler orta yerlerine alurlar gayrî kullara inanmazlar. Yeniçerilerin orta yerinde olur, mâdâm ki ceng bertaraf olmaya sa'âdetlü ve azametlü ve şevketlü ve devletlü pâdişâh hazretlerini ve vezîr-i a'zamı çadırına salıvirmezler, yeniçeriler dört etrafın kuşadub muhâfaza iderler. Kānûn budur ki alâ tarîki'l icmâl beyân olundu. Geldik yine yeniçeri meydânına. ${ }^{30}$ Bir gün gāzî hünkâr meydâna gelüb kullarına tüfenk attırmak sadedinde iken yirmi bir ağa bölügün aşçısı Gedük ${ }^{31}$ Ahmed demekle ma'rûf kimesne ziyâde bahâdır kimse olub nice def'a gāzî hünkârın huzûruna dil ve baş getürüb yararlığı sâbit olmuşdı. Evvela $^{32}$ aşçı gāzî hünkâra arz-1 hal virüb mefhûmunda; "Hünkârım yeniçeri kullarına üçer akçe mîrî verilmek üzere Karacan koyunundan bizzât sa'âdetlü hünkârımın matbah-1 âmiresinden bu kadar etler ihsân buyurdunuz. Allah te'âla sa'âdetlü hünkârımın eksiklüğin göstermeyüb bu ocağa ihsân buyurduğun ihsânların ıvazına kulların şükrin itmege bir vechile iktidârları yok velakîn sadaka ve ihsân buyurdığın etleri cümle aşçı kulların varub İstanbul'da kassab dükkânların beklerüz alınca azîm zahmetler çekilür. Gāzî hünkârım hazretleri mercûdur ki cümle aşçı kullarına merhamet buyurulub ocağa sadaka ihsân buyurduğun etlerimizi bu ihyâ buyurduğun bir köşesinde İstanbul dükkânlarından ayırub bu gāzî kulların meydânına getürüb zâbitlerinma ‘rifetiyle odalarımıza tevzî‘ ve teslîm olunmak bâbında hatt-1 hümâyûn sadaka ve ihsân oluna" deyu bu arz-1hâli (6a) gāzî hünkâr kıraât buyurduklarında kahkaha ile gülüb; "Aşçı aşçı ceddim ruhiçün bu gice bu ahvâl benim hatırıma geldi, Elhamdülillâhı Te'âla kullarımın tedbîrleri gönül birliğine delildir” deyu ol sa'at sekiz tomruğı İstanbul içinde olan dükkânlardan ayırub sekiz tomruğı meydâna getürüb vaz‘ eylemişdir. Ve ba'de aşçılara namâz kılmak içün bir mescid binâ idüb ve bir masura su virmek üzere ve

29 Türk Tarih Kurumu Küthanesi’ndeki nüshada "pazben" şeklinde yazılıdır. Diğer nüshada "bir bend" şekli mevcuttur. Bu mecmuada

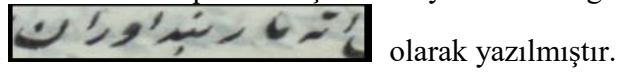

${ }^{30}$ Kanun budur kiden buraya kadar kısım kırmızı mürekkeple yazılmıştır.

${ }^{31}$ İsim burada Gedük şeklinde yazılmış olup sonrakiler Gedik şeklindedir.

${ }^{32}$ Metinde kelime "evvelâ" şeklinde yazılmıştır. Diğer nüshalarda "ol” yazılıdır. 
bir musluk ve bir ayakyolu binâ idüb ve kullarımın ta 'yînâtı birde ${ }^{33}$ gerekdir deyü meydânda bir mahzen binâ idüb yağ ve bal ve pirinç ve mum virilmek içün ve buyurur ki; "Şimdi bu kassâblar yeniçeri kullarımın hidmetkârı oldu" deyu her tomruğa ikişer zimmı usta ve dörder hidmetkâr ta 'yîn buyurdı ve bu zimmîlerin cümlesin harâclardan ve sâir tekâlif alınmamak içün mu'âf ve müsellem itmişlerdir. Ve mübârek eline kalem alub bir hatt-1 hümâyûn yazmışdır ki; "Benim kullarımın tomruklarında eger Karaman koyunu ve eger keçi etleri ve sâir arık ve bayatetler getürüb bu sekiz tomrukda kullarıma virürlerse üzerlerine nâzır ta'yîn olunan başçavuş ve mezbûr zimmîlerin üzerine hâkim eylediğim başdeveci bir vechile rızâ virüb veyahud i'mâz-1 'ayn iderlerse Allah Azimüş-şanın ve cemî' yaradılmışın la'neti anların üzerine olsun" deyü bu minvâl üzere te'kîd ile bir la'netnâme yazuvirüb başçavuş ve mezbûr başdevecinin eline hatt-1 hümâyûn virir kim bu zimmî meydân kassâbları eger kullarıma arık veyahud Karaman koyunu ve keçi etlerin veya bayat etler getürürlerse saksonlara virile deyu bu minvâl üzere herşeyi tertîb eyleyüb bâlâda mestûr olunduğı üzere merhûm gāzî hünkâr Yeniçeri Ocağı halkına muhabbet eyleyub bu kadar ihsânlar (6b) idüb yedi def'a la'netnâme yazub birin kulkethüdâsına ve birin başçavuşa ve birin başdeveciye ve birin yedi nefer gāzîlere virmişdir. Ve bunlardan sonra Gāzî Sultân Süleyman bir seneden sonra aşçı Gedik Ahmed'i meşîn ${ }^{34}$ ile divâna getürüb üzerine kaftan giydirüb ihtisâb ağalığın ihsân buyurub ve eline bir kavî hatt-1 hümâyûn virdi kim; "Bu şehirde lahm beşer akçeye çıkdı vesâir zehâir kim kezâlik aslı üzere ahvâlin bil ve anla, emrime muhâlefet iden kimesnenin hakkından gel, rikâb-1 hümâyûnuma 'arza ihtiyaç değildir. Göreyim seni er ol, baş yar sonra senin hakkından gelürüm” deyü ziyâde tenbîh ve te'kîdden sonra mezbûr aşçı taşra çıkdıkda kol idüp ol gün bütün İstanbul'u gezdikde on bir adamı navlunculardan salb idüb ve ertesi gün kol ittükde kassâbbaşıyı ve kassâblar kethüdâsın ve etmekçibaşıyı ve etmekçiler kethüdâsın salb edüb gāzî hünkâra arz olundukda ziyâde haz idüb sürûrundan bizzat kendüleri Mevlevî şekline girub İstanbul'u gezdükde mezur aşçıyı huzûr-1 şerîflerine getürüb hil'at-1 fâhire ihsân idüb ve bin altun in'âm eyledi. Bundan sonra mezbûr aşçı kol ettikde görür kim et ve etmek ve sâir eşya dağlar gibi yığılmış, alur satar yok bir vukiyye lahm ve üç akçeye ve bir buçuk vukiyye etmek bir akçeye ve bir vukiyye revgan-1 sâde ve sâfî on akçeye ve on iki kutu kızıl mum

\footnotetext{
${ }^{33}$ Metinde kelime "birde" veya "yerde" okunacak şekilde yazılmıştır. Diğer nüshalarda "bir yerde" ifadesi vardır.

${ }^{34}$ Aşçıların giydiği hususi kıyafet kastedilmektedir.
} 
bir akçeye ve sâir eşyalar buna göre. Beş sene ihtisâb ağası olub ziyâde zabt olduğu ecilden gāzî hünkâr ikinci vezîr idüb kubbenişîn oldukda bir iki seneden sonra vezîr-i a'zam âhirete intikâl edüb mezbûr Gedik Ahmed Paşa'yı vezîr idüb haftada bir büyük kol idüb (7a) yeniçeri ağasıyla ve İstanbul efendisi ve istisâb ağası ve kayıkçıların çorbacısı ile gelüb Unkapanı'nda karâr iderlerdi. Bir kile buğday alub un ittürüb ve yoğurub ve etmek tabh itdikde numûme dedikleri budur ana göre narh iderlerdi vesselâm.

Sa‘âdetlü pâdişâh-ı âlempenâh hazretleri veyahud serdâr vezîr-i a'zâm olub sefere gitdiklerinde büyük alay tertîbini beyân ider, nakl ve işâret olunmuşdur. Ve mu'azzam şehre gelüb alay olmak lâzım geldikde başçavuş ve ortaçavuş ve küçükçavuş ve başyazıcı alay dizmek bunların üzerine lâzımdır gayri kimseye mahsûs değildir. Başçavuşa lâyık olan budur ki bu zikr olunan adamlar ile mukaddem selâm yerin bakub tahmîl ideler. En iptidâ sakabaşı cümle sakalar ile başda dururlar ve sakabaşının karşusunda başyayabaşının bayrağı durur ve sâir bayraklar umûmen başyayabaşı bayrağı altında tertîb üzere dururlar. Ve ba'de bayraklardan sonra iki keçeli neferât dizilüb neferât tamam oldukda çorbacılar dururlar. Ve ba'de vezîr-i a'zam alayı ile gelür ağayı selamlar, ağa hazretleri iki üç adım atıyla karşu varub selâmın alur ba'de kıçı üzerine gelür. Sâhib-i devlet geçdikde evvelki kānûn üzere ağanın önüne düşüb otağa götürürler, ağayı selamlayub ve ba'de kethüdâ beg ağayı otağına kodukdan sonra kethüdâ beg ve başçavuş ve ortaçavuş ve küçükçavuş ve bölükbaşı ağalar ağanın otağından kethüdâ begin önüne düşüb çadırına götürürler, çavuşlar ve bölükbaşılar kethüdâ begi selâmlayub herkes çadırlu çadırına gider.

\section{Vezîr-i a'zâm ile Yeniçeri Ocağı sefere gitdiklerinde büyük alay (7b)} tertîbidir ki zikr olunur. Konağdan kalkmazdan evvel en ibtidâ yeniçeri ağasının tuğu gider. Bunun ardınca sa'âdetlü kethüdâ begin büyük alay bayrağı gider. $\mathrm{Bu}$ bayrağın sağında başyayabaşı bayrağı ve solunda başçavuş bayrağı atbaşı beraber giderler. Bunun ardınca umûmen yayan pür silâh yeniçeriler gider, bunun ardınca küçükçavuş ve ortaçavuş ve başçavuş ve ocak imâmı ve hâseki ağalar ve turnacıbaşı ve saksoncubaşı ve zağarcıbaşı ve kethüdâ begin ve efendinin yedekleri giderler. Tertîb üzere bu yedeklerün ardınca ocak ağaları küçükçavuş ve ortaçavuş ve başçavuş ve ocak imâmı ve hâseki ağalar ve turnacıbaşı ve saksoncubaşı ve zağarcıbaşı ve kethüdâ beg ve efendi giderler. Bunun ardınca sa'âdetlü yeniçeri ağası hazretlerinin yedekleri gider. Yedekleri ardınca İmâm-1 a'zâm hazretlerinin 
sancağ1 gider, bu sancağın ardınca sa‘âdetlü yeniçeri ağası ve ardınca kendünün sancağ1 ve büyük alay bayrağı ve göndereciler gider. Bunun ardınca mehterhânesi ve mehterhânenin ardınca kethüdâ gider. Önünde ikişer ikişer yoldaşları gümüş toplu harbeler ile giderler ve bunun ardınca sağ tarafında yayabaşının çorvacıları ve deveci ağalar kukalarıly umûm tertîb üzere giderler ve solunda (bölükbaşılar umûm üzere kukalarıla tertîb üzere giderler.) ${ }^{35}$ Bunların ardınca sağda yayabaşıların odabaşıları (ve solunda bölükbaşıların odabaşıları) ${ }^{36}$ tertîb üzere atbaşı beraber giderler ve bunların ardınca bayrakdârlar bayraklarıyla ve bu uslûb üzere sağda yayabaşıların bayrakları ve solda bölükbaşıların bayrakları umûm üzere ikişer ikişer atbaşı beraber giderler. Ve bunların ardınca vezîr-i a'zam hazretlerinin alayı giderler. Yola gitdiklerinde bu minvâl-i meşrûh üzere giderler ve ba'de çadırlarına yakın geldiklerinde vezîr-i a'zam $\left(\boldsymbol{8 a} \boldsymbol{~}^{37}\right.$ hazretlerine selâm durmak içün bir cânibde sakabaşı bayrağı dikülür ve sakaları tertîb iderler. Ve sakabaşıyı gördüklerinde cümle çorbacılara ve odababaşılara ve bayrakdârlara destûr olur ve bölükbaşıların bayrakdârları sakabaşı sırasında dururlar ve başyayabaşının bayrağı sakabaşının karşusunda dikilür ve sâir yayabaşıların bayrakdârları tertîb üzere dizilürlerve yayabaşılar tertîb üzere durular ta kethüdâ beg bayrağı gelince. Kethüdâ begin bayrağı geldükde başçavuş bayră̆1 gelüb altında durur ve ba'de ocak ağaları tertîb üzere dururlar ve başda ağa hazretleri durur ve başbayrakdâr ve İmâm-1 a'zâm bayrağı ve göndereciler ve mehterhâne sa'âdetlü ağanın ardında dururlar. Vezîr-i a'zam hazretlerinin alayı gelür aralarından geçerler. Vezîr-i a'zam iki tarafina selâm virerek ağanın yanına geldikde bir iki adım ağa hazretleri at ile karşu varub selâmın alub ba'de kıçı üzerine yerine gelüb vezîr-i a'zam geçdikde cümle bölükbaşılar ve yayabaşılar ve bayrakdârlar at kaldırub yeniçeri ağasının otağı önünde iki keçeli atıyla dururlar. Bölükbaşıların cümlesi ve başçavuş ve kethüdâyeri ve kethüdâ beg ve ortaçavuş ve küçükçavuş atlarından inüb ağanın otağı önünde tertîb üzere durub ağanın selâmın alurlar ve ba'de yayabaşılar çadırlı çadırlarına gider.

Ocağın kānûnu budur ki ayda bir kere Yeniçeri Ocağı vezîr-i a'zam hazretlerine büyük kol ile gitmek lâzım geldikde başyazıcıya emreder kim odalara tenbîh; "Yarın cum'a gündür dîvan esbâbları ile kapuya gelsünler, ağa hazretleri büyük kol ile sâhib-i devlet hazretlerine gitse gerekdir." Cümle

\footnotetext{
${ }^{35}$ Parantez içi kısım metin kenarına ilave edilmiştir.

${ }^{36}$ Parantez içi kısım metin kenarına ilave edilmiştir.

${ }^{37}$ Vezir kelimesi önceki sayfa yazılıdır.
} 
bölükbaşılar ( $8 \boldsymbol{b})$ ve yayabaşılar ve deveci ağalar ve hâseki ağalar ve turnacıbaşı ve saksoncubaşı ve zağarcıbaşı ve dört solakbaşılar ve kethüdâ beg ve başçavuş ve ortaçavuş ve küçükçavuş vesâir ocak erbâbı bu zikr olunan ağaların cümlesi ağakapusunda dîvan esbâblarıyla cem‘ olurlar. Cum'a namâzın kıldıkdan sonra cümle ocak ağaları atlarına binerler ve en ibtidâ üsküfleriyle kapu kethüdâları gider. Anın ardınca at ile bölükbaşılar giderler, bunların ardınca yayabaşılar giderler, bunların ardınca yayabaşıların deveciler ağaları giderler, bunların ardınca başçavuş ve (ocak imâmı giderler, bunların ardınca hâseki ağalar) ${ }^{38}$, bunların ardınca turnacıbaşı ve saksoncubaşı ve zağarcıbaşı ve dört solakbaşılar giderler. Ve ardlarınca kulkethüdâsı gider ve bunun ardınca yeniçeri kâtibi ve sekbânbaşı ve İstanbul ağası ve Rumili ağası ve Anadolu ağası ve fodlakâtibi giderler. Ve bunlardan sonra serâser kuşaklı ve üsküflü mumcu ağalar giderler. Ba‘de küçükçavuş ve ortaçavuş kırmızı dolamalarıyla ve seraser kuşaklarıyla ağanın önünde yürürler ve ortaçavuş ağanın sedefkârî değneğin götürür ve âriyeti çavuşân serâser kuşaklarıyla ve üsküfleriyle mumcular aralarında yürürler. Ve sa‘âdetlü yeniçeri ağasının sağ tarafında başmehter ve sol tarafında ortamehter eteklerin tutarlar ve dört tüfenkçiler kırmızı dolamalarıyla ikisi bir tarafdan ve ikisi bir tarafdan yürürler. Bu minvâl üzere paşa kapusuna varduklarında cümlesi atlarından inerler ve ağayı atından indürürler. Ağanın bir koltuğuna kulkethüdâsı ve bir koltuğuna başçavuş girer ve ba'de divânhâneden paşaya ${ }^{39}$ girdüklerinde evvel yeniçeri ağası el öper. Andan sekbânbaşı andan yeniçeri kâtibi andan İstanbul ağası andan fodlakâtibi andan Anadolu (9a) ağası andan Rumili ağası andan kulkethüdâsı andan dört solakbaşılar andan zağarcıbaşı ve saksoncubaşı andan turnacıbaşı ve andan tertîb üzere dört hâseki ağalar andan başçavuş andan ocak imâmı kalurlar. Bunların mâ‘âdası taşraya çıkarlar, divânhânede tertîb üzere oturular. Vezîr-i a'zamın yanında kalan ocak ağaları oturub kahve ve şerbet içerler ve taşrada olan ağalara dahi kahve ve şerbet getürüb içerler. Ve bile gelen neferât yoldaşlara kahveciler şerbet doldurub aşağıda olanlar dahi azîm ve vâfir şerbet içürürlerve içerüde olan ağalara kethüdâ beg icâzet virür. Sekbânbaş1 ve yeniçeri kâtibi ve İstanbul ağası ve fodla kâtibi ve Anadolu ağası ve Rumili ağası ve dört solakbaşı ve zağarcıbaşı ve saksoncubaşı ve turnacıbaşı ve dört hâseki ağalar ve ocak imâmı içerüden çıkarlar ve deveci ağalara ve yayabaşılara icâzet olur evlerine giderler. Ve kalan ağalar ki sa'âdetlü yeniçeri ağası ve kulkethüdâsı ve başçavuş ve

\footnotetext{
${ }^{38}$ Parantez içi kısım metin kenarına ilave edilmiştir.

${ }^{39}$ Burası "paşa kapusuna girdüklerinde" diye okunması gerekir.
} 
ortaçavuş ve küçükçavuş ve bölükbaş1lar ve mumcılar kalurlar. Yeniçeri ağası vezîr-i a'zamdan kalkar, atına süvâr olur andan (kethüdâ beg süvâr olur andan başvavuş andan) ${ }^{40}$ bölükbaşılar süvar olurlar. İptidâ kapu kethüdâları gider, andan bölükbaşılar at ile giderler andan başçavuş gider andan kulkethüdâsı gider andan tertîb üzere mumcılar ikişer ikişer giderler andan küçükçavuş andan ortaçavuşu yayangider. Ağanın sedefkârî değnegin götürür ağanın önünde yürürler. Andan sa'âdetlü yeniçeriağası gider. Bir tarafda başmehter ve bir tarafda ortamehter eteklerin dutarlar, dört tüfenkçiler ağanın ikisi bir tarafinda ve ikisi bir tarafinda giderler. Yolda (9b) giderken kapukethüdâları bir serhoşa rastgeldiklerinde dutup ağanın önüne getürdüklerinde döğmek lâzım geldikde bölükbaşıların cümlesi atlarından inerler ağanın yanına gelürler. Tertîb üzere durub serhoşi ağanın huzurına getürdükde ve döğmek lâzım geldikde mumcular falakayı dutub acemi bölükbaşıları ellerine değnek alub dutulan serhoşa değnek ururular. Değnekden sonra cümle bölükbaşılar atlarına süvâr olub kapukethüdâlarının ardınca giderler. Bu minvâl üzere kol kolaşub sa'âdetlü ağayı kapuya getürdüklerinde atdan inüb tertîb üzere selâma dururlar. Kethüdâyeri karşu gelür ağanın etegine girer ve kehüdâ beg ve başçavuş atlarından inerler ağayı atından indürürler. Ağa yerinde oturub dahi serhoş dutulmuş var ise döğmek lâzım geldikde ol gün yine mumcular falakayı dutarlar ve bölükbaşılar değnek ururular. Ba'de ağayı yerinden kaldırub odaya girdikde kethüdâyeri taşraya taşraya çıkar bölükbaşı ağalara selâm verüb icâzet verirler evlerine giderler. Başçavuş, ortaçavuş, küçükçavuş ve kethüdâ beg perişanî sarığıyla ve önünde iki keçeli yeniçeri yoldaşları kethüdâ begin önüne düşüb evine götürdüklerinde atlarından inüb kethüdâ beg koltuğuna girüb odasına korlar. Ba'de dest-bûs idüp herkes evlerine giderler. İşte kānûn kâ‘ide budur ki zikr ve işâret olunmuşdur. La'net ana kim bu kâ'ideyi tebdîl ve ta'yîr eyleye.

Ramazân-ı şerîf-i mübârek ile ve ıyd-ı şerîf geldikde bayramlaşmak içün vezîr-i a'zam hazretlerine bütün ocak erbâbı ile gitmek lâzım geldikde başyazıcıya (10a) emr iderler;"Yarın ocak halkına tenbîh eyle divân esbablarıyla kapuya gelsünler, vezîr-i a'zam hazretlerine Ramazan mübârekliğine ve 1yd-i şerîf mübârekliğine giderler” deyü. Ocak ağaları ve deveci ağalar ve yayabaşılar ve bölükbaşı ağalar ve çavuşlar ve mumcular ağakapusunda divân esbâblarıyla cümle hâzır olurlar. Gitmek lâzım geldikde en ibtidâ kapukethüdâları üsküfleriyle giderler, bundan sonra yayabaşılar giderler, bunların ardınca deveci ağalar, bunun

\footnotetext{
${ }^{40}$ Parantez içi kısım metin kenarına ilave edilmiştir.
} 
ardınca baş̧̧avuş ve ocak imâmı giderler, bunların ardınca dört hâseki ağalar giderler, bunların ardınca turnacı, saksoncu ve zağarcı ve dört solakbaşılar, bunların ardınca kulkethüdâsı bunun ardınca İstanbul ağası ve Anadolu ağası ve Rumili ağası ve fodla kâtibi ve yeniçeri kâtibi bunların ardınca sekbânbaşı bunun ardınca yayan bölükbaşılar gider. Başbölükbaşı, ağanın sağında ve ikinci bölükbaşı solunda ağanın eteklerin dutarlar ve küçükçavuş ve ortaçavuş kırmızı dolamalarıyla ağanın önünde yürürler ve ortaçavuş ağanın sedefkârî değneğin götürür. Sa'âdetlü ağa hazretleri selîmî ile dört tüfenkçiler kırmızı dolamalarıyla ikisi sağında ve ikisi solunda yürürler ve başmehter ve ortamehter ağanın yanında tüfenkçilerin önünde yürürler. $\mathrm{Bu}$ minvâl üzere vezîr-i a'zam hazretlerinin sarayına vardıklarında muhzır ağa sorgucıyla ağaya karşu gelüb etegine girer. Saraya varduklarında cümlesi atlarından inüb yukaruda zikr ve tertîb olunduğu üzere cümlesi el öperler. Evvel yeniçeri ağası ve sekbânbaş1 ve yeniçeri kâtibi ve İstanbul ağası ve fodla kâtibi ve Anadolu ağası ve Rumili (10b) ağası ve kulkethüdâsı ve dört solakbaşı ve zağarc1 ve saksoncu ve turnacı ve dört hâseki ve başçavuş ve ocak imâmı vezîr-i a'zam hazretlerinin yanında otururlar, sâir deveci ağalar ve yayabaş1lar ve bölükbaşılar divânhânede el öpdükden sonra tertîb üzere otururlar. İçerüde vezîr-i a'zam yanında oturan ağaların hâl hâtırların sordukdan sonra kahve ve şerbet ve buhur tütsü mikdârı eğlenürler ve kethüdâ beg ve başçavuş ve kethüdâyeri oturmayub muhzır ağa ile bu dört ağalar beraber ayak üzere dururlar. Ve ba'de kulkethüdâsı ocak ağalarına işâret eder, sekbânbaşı ve yeniçeri kâtibi ve İstanbul ağası ve fodla kâtibi ve Anadolu ağası ve Rumili ağası ve dört solakbaşılar ve zağarcıbaşı ve saksoncubaşı ve turnacı ve dört hâseki ve ocak imâmı ve taşrada olan deveci ağalar ve yayabaşılara icâzet olur, herkes evlerine giderler. Yeniçeri ağası ve kulkethüdâsı ve başçavuş ve kethüdâyeri bir mikdâr vezîr-i a'zamın yanında eğlenürler, bir tenhâ sözleri var ise vezîr-i a'zam hazretlerine i'lâm ederler. Ba'de yeniçeri ağası kalkup tekrâr dest-bûs eder taşra çıkar, atına biner bölükbaşılar yayan önüne düşerler, kulkethüdâsı ve başçavuş önünde yürürler, ortaçavuş ve küçükçavuş ve sâir çavuşân önünde yürürler. Bayramlaşmak içün ikinci kubbenişîn vezîre varub atlarından inerler ağayı indirirler, kulkethüdâsı ve başçavuş ağanın koltuğuna girerler. Divânhâneye çıkdıklarında içerü girmek lâzım geldükde evvel yeniçeri ağası andan kulkethüdâsı andan başçavuş andan küçükçavuş ve çavuşân andan bölükbaşllar tertîb üzere el öperler. Cümlesi el öpdükden (11a) sonra sa'âdetlü yeniçeri ağasıyla görüşürler. Ba'de çıkarlar atlarına süvâr olub bu minvâl üzere ve bu tertîb ile üçüncü vezîre 
varırlar. Andan dördüncü vezîre andan beşinci vezîre bu tertîb ve bu uslûb üzere altıncı ve yedince vezîre varub bayramlaşurlar. Andan yine bu uslûb ağakapısına yakın geldiklerinde Süleymaniye Cami'i köşesinde kethüdâyeri iner, ağanın sağ tarafındaki etegine girer ve başbölükbaşı sol etegine girer ve kapuya girdüklerinde bölükbaşılar tertîb üzere dururlar çavuşan kezâlik dururlar. Kulkethüdâsı ve başçavuş atlarından atlarından inerler ağanın koltuğuna girüb atından indürürler. Yeniçeri ağası bunlara selâm verüb tekrar kethüdâ beg ve başçavuş koltuğuna girerler. Odaya girdiklerinde kethüdâyeri taşra çıkar, bölükbaşılara selâm virüb icâzet virür, herkes evlerine giderler. Ba'de kulkethüdâsı ve başçavuş ağanın yanında bir mikdâr eğlenürler. Ba'de kulkethüdâsı kalkar ağanın destin bûs eder ve ba'de başçavuş ortaçavuş ve küçükçavuş perişanî sarıklarıyla kethüdâ begin önüne düşerler evlerine götürürler. Ba'de başçavuş ortaçavuş ve küçükçavuş atlarından inerler kulkethüdâsın indirirler. Başçavuş ile ortaçavuş kethüdâ begin koltuğuna girüb odasına korlar. Ba'de dest-bûs edüb başçavuş ile ortaçavuş önüne düşüb ortaçavuş ve küçükçavuş ve başçavuşun selâmına dururlar. Başçavuş selâmın aldıkda herkes sürûr ve safâ ile evlerine giderler.

\section{Der-beyân-ı bayramlaşmak}

Bayram gicesi beşinci sa'atte cümle ocak halkı divân esbâblarıyla kapuya gelürler, (11b) sa'âdetlü ağa ile tertîb üzere dîvana giderler, içerüye girerler, herkes yerlerinde tertîb üzere otururlar. Ba'de vüzerâ gelürler anlar dahi kubbeye girüb otururlar. Ba'de vezîr-i a'zam gelür kubbede oturan vüzerâya sakabaşı "buyura" deyu çağurub vüzerâ taşra çıkarlar. Kubbe önünde tertîb üzere dururlar vezîr-i a'zamı selâmlarlar. Vezîr-i a'zam önüne düşer kubbeye girerler tertîb üzere oturular. Şâfi‘î vaktinde sabâh namâzından sonra yeniçeri ağası ve sekbânbaşı ve yeniçeri kâtibi ve fodla kâtibi ve Rumili ağası ve Anadolu ağası ve kulkethüdâsı ve zağarcıbaş1 ve saksoncubaşı ve dört solakbaşı ve turnacıbaş1 ve dört hâseki ve başçavuş ve ocak imâmı ve başdeveci ve başyayabaşı bunların önüne yeniçeri ağası düşüb kubbeye girüb vezîr-i a'zam ile bayramlaşurlar. Tertîb üzere ba'de yine yerüne gelürler otururlar. Ba'de sa'âdetlü hünkâr taşra çıkub tahtında karâr ederandan hanzâdeler gelüb el öperler andan nakîbüleşrâf el öper andan şeyhülislâm andan vüzerâ el öper. Ba'de yeniçeri ağası yerinden kalkub ocak halkının önüne düşer. Ardında sekbânbaşı andan efendi andan İstanbul ağası andan Anadolu ağası andan Rumili ağası andan fodla kâtibi andan kulkethüdâs1 andan 
dört solakbaş1 (andan zağarcıbaşı, saksoncubaş1, turnacıbaşı) ${ }^{41}$ dört hâseki, andan başçavuş andan ocak imâmı andan başdeveci andan başyayabaşı andan sâir deveci ağalar tertîb üzere hünkârın karşusunda dururlar. Vüzerâ tamam oldukda bu zikr olunduğu üzere hünkârdan el öperler. Andan ocak halkı gelürler yerlü yerinde karâr ederler, birazcık yerlerinde otururlar. Hünkârdan (12a) el öper adamlar az kaldıkda ocak halkına icâzet olur, bayram namâzına giderler. Ağa yerinden kalkar kulkethüdâsı ve başçavuş ve kethüdâyeri taşra çıkarlar ağaya katılanurlar, ağa gelür atına bindirirler. Ağa gelür ağaçların yanlarında atla dururlar (ve kulkethüdâsı biner, bir hayli uzak atla durur $)^{42}$ ve başçavuş ve kethüdâyeri yayan ağanın eteginde dururlar. Sa'âdetlü hünkârın hazînedârı hünkârın seccâdesin ta'zîm ve tekrîm [ile $]^{43}$ götürür. Seccâdeden sonra hünkâr atına biner. Hünkâr orta kapuya geldükde taşra çıtığı sa'at yeniçeri ağası atla dört beş kadem acele ile hünkâra karşu varır. Hünkârun selâmun almağa gitdikde başçavuş ve kethüdâyeri atlarına binerler, kulkethüdâsı bunların ardınca acele ile gider. Gelürler cami'in kapusu önünde dururlar ve dört solakbaşılar ve zağarcıbaşı ve saksoncubaş1 ve turnacıbaş1 ve dört hâseki ağalar hünkârın eteklerine cami'e gelince nevbetce girerler. Hünkâr cami'e girdikde herkes bayram namâzın kıldıkda ocak halkı hutbeye katılanmayub başçavuş ve ortaçavuş ve küçükçavuş ve başyazıcı iki kapu arasında iki üç sıra yeniçerileri dizerler. Cümle ocak halkı aralarından geçerler. Cümle ocak halkı ki sekbânbâşı ve yeniçeri kâtibi ve İstanbul ağası ve Anadolu ağası ve Rumili ağası ve fodla kâtibi vesâir yayabaşılar ve deveci ağalar ve acemi çorbacıları ve sekbân ve zağarc1 cümlesi içerü girüb tertîb üzere yerlerinde karâr iderler. Ve kulkethüdâs1 ve başçavuş ve kethüdâyeri ve ortaçavuş ve küçükçavuş bâb-1 hümâyûnda kethüdâ begin altında tertîb üzere dururlar. Ba'de yeniçeri ağası gelür içerü girüb hünkârı indirmege müntazır olur. Ba'de vüzerâgelür selâm vererek geçerler, atlarından inerler. Anlar dahi tertîb üzere içerüye girüb ba'de (12b) vezîr-i a'zam gelür selâm vererek geçer, atından iner, vüzerâ ardınca gider. Ba'de hünkâr gelür, kulkethüdâsına ve kapu önünde duran ağalara selâm verir. Hünkâr içerü girüb atından inmeğe müntazır olurlar. Atdan indiği haberin başyazıcı virdikde kulkethüdâsı ve başçavuş ve kethüdâyeri ve ortaçavuş ve küçükçavuş yeniçerileri muhkem zapt iderler. Başyazıcı hünkârın atdan indüği haberin kulkethüdâsına virdikde kulkethüdâsı ve başçavuş ve kethüdâyeri ve ortaçavuş ve küçükçavuş

\footnotetext{
${ }^{41}$ Parantez içi kısım metin kenarına ilave edilmiştir.

${ }^{42}$ Parantez içi kısım metin kenarına ilave edilmiştir.

${ }^{43}$ Burada olması gereken "ile" edatı unutulmuştur.
} 
kapu arasında kaçarlar. Yeniçerilere icâzet olur içerü girüb yemek kaparlar. Ba ‘de herkes yerlü yerinde karâr ider, ba'de divân bozulub tertîb üzere ağakapusuna gelürler.

\section{Hazâpâdişâhlara du'â}

Gelin gāzîler du'â idelim, evvel Allah'ın birligiçün pâdişâhımızın eyyâm-1 devletiçün, Sultân Bâyezid-i Veli ruhiçün, Sultân Süleyman Gāzî ruhiçün, Sultân Selîm Gāzî ruhiçün, Sultân Murâd Gāzî ruhiçün, Sultân Mehmed Gāzî ruhiçün, Sultân Ahmed Gāzî ruhiçün, Sultân Osman Gāzî ruhiçün, Sultân Murâd Gāzî ruhiçün, Sultân İbrahim Gāzî ruhiçün, paşalarımız safâlığıçün, ağamız safâlığıçün, gönüller murâdıçün, âkibet hayırlığıçün, imân yoldaşlığıçün bu meydândan gelmiş geçmiş gāzîler ruhiçün, bâkilerimiz selâmetiçün, bizi du'âdan unutma diyenler içün ve du'âya muhtâc olan cânlar içün üzerimizde hakkı olan müslümanlar içün, tuzun etmegin yedügümüz karındâşlarımız içün Hazret-i Resûlüllâh Sallallâh 'Aleyh ve Sellemin pâk münevver mudahhar rûh-i şerîfleri içün, evlâdı içün, ashâb1 içün çıhâr-1 yârlar ervâhı içün, Sultân Hâcı Bektaş-1 Velî ruhiçün gelmiş geçmiş ulemâ ve sulehâ, şeyh ve meşâyîh (sadât ruhlarıçün baki ulemâ ve sulehâ ve meşâyîh) ${ }^{44}$ selâmetligiçün, pâdişâhımız selâmetligiçün, cemî‘ geçmiş (13a) ehl-i imân ruhlarıçün, Allâh rızâsıçün. Evveli ve âhiri selâvatiyle Fâtiha okuyanlar dünyâdan ahirete imân ile gide vedu'âlar kabulluğuna peygamberin pâk rûhuna salavât.

Defter oldur ki dîvan oldukda arz günlerinde vezîr-i a'zam ve yeniçeri ağasına ve sâir dîvan halkına asesbaşı ve kapukethüdâsı yediyle tevzí‘ olunan akîde şekeri beyân ider kānûn-1 kadîmdir. Aynîyle işâret olunmuşdur.

\begin{tabular}{|c|c|c|c|}
\hline $\begin{array}{c}\text { Vezîr-i a'zâm } \\
\text { dirhem 200. }\end{array}$ & $\begin{array}{c}\text { Yeniçeri Ağasına } \\
\text { dirhem 100. }\end{array}$ & $\begin{array}{c}\text { Sersekbânân } \\
\text { dirhem 100. }\end{array}$ & $\begin{array}{c}\text { Yeniçeri Kâtibi } \\
\text { dirhem 30. }\end{array}$ \\
\hline $\begin{array}{c}\text { Kethüdâ Beg } \\
\text { dirhem 100. }\end{array}$ & Sersolak & Sersolak & Sersolak \\
\hline dirhem 15. & dirhem 15. & dirhem 15. \\
\hline Sersolak & Serzağarî & Sersaksonî & Serturnaî \\
dirhem 15. & dirhem 25. & dirhem 25. & dirhem 20. \\
\hline Serçavuş & Muhzır Ağa & Kethüdâ-i Cây & Hâseki Ağa \\
dirhem 50. & dirhem 40. & dirhem 25. & dirhem 15. \\
\hline
\end{tabular}

${ }^{44}$ Parantez içi kısım metin kenarına ilave edilmiştir. 


\begin{tabular}{|c|c|c|c|}
\hline $\begin{array}{c}\text { Hâseki Ağa } \\
\text { dirhem 15. }\end{array}$ & $\begin{array}{c}\text { Hâseki Ağa } \\
\text { dirhem 15. }\end{array}$ & $\begin{array}{c}\text { Hâseki Ağa } \\
\text { dirhem 15. }\end{array}$ & $\begin{array}{c}\text { Başyayabaş1 } \\
\text { dirhem 25. }\end{array}$ \\
\hline $\begin{array}{c}\text { Başbölükbaş1 } \\
\text { dirhem 25. }\end{array}$ & $\begin{array}{c}\text { Çavuş-1 meyâne } \\
\text { dirhem 15. }\end{array}$ & $\begin{array}{c}\text { Çavuş-1 küçük } \\
\text { dirhem 15. }\end{array}$ & $\begin{array}{c}\text { Mehterbaş1 } \\
\text { dirhem 15. }\end{array}$ \\
\hline $\begin{array}{c}\text { Mehter-i meyâne } \\
\text { dirhem 15. }\end{array}$ & $\begin{array}{c}\text { Ta'lîmhâneci } \\
\text { dirhem 15. }\end{array}$ & $\begin{array}{c}\text { Câmedân-1 ağa } \\
\text { dirhem 15. }\end{array}$ & $\begin{array}{c}\text { Çukadâr-1 ağa } \\
\text { dirhem 15. }\end{array}$ \\
\hline $\begin{array}{c}\text { Serrâc-1 yapuk } \\
\text { dirhem 15. }\end{array}$ & $\begin{array}{c}\text { Serrâc-1 kethüdâ beg } \\
\text { dirhem 15. }\end{array}$ & $\begin{array}{c}\text { Tüfenkçiyân-1 ağa } \\
\text { dirhem 40. }\end{array}$ & $\begin{array}{c}\text { Kâtibân-1 baş } \\
\text { dirhem 50. }\end{array}$ \\
\hline $\begin{array}{c}\text { Kâtib-i kethüdâ } \\
\text { beg dirhem 15. }\end{array}$ & $\begin{array}{c}\text { Başkapukethüdâs1 } \\
\text { dirhem . }\end{array}$ & $\begin{array}{c}\text { Seroda-i 1. bölük } \\
\text { dirhem. }\end{array}$ & $\begin{array}{c}\text { Seroda-i 5. bölük } \\
\text { dirhem.(13b) }\end{array}$ \\
\hline $\begin{array}{c}\text { Kâtib-i 1. bölük } \\
\text { dirhem. }{ }^{45}\end{array}$ & $\begin{array}{c}\text { Seroda-i kethüdâ } \\
\text { dirhem 5. }\end{array}$ & $\begin{array}{c}\text { Bölük ağalar1 } \\
\text { sipah dirhem 50 } \\
(10 \text { 'ar dirhem) }\end{array}$ & $\begin{array}{c}\text { Seroda-i muhzır } \\
\text { dirhem 5. }\end{array}$ \\
\hline \multicolumn{3}{|c}{ Ocağın kâtibleri } \\
dirhem 40
\end{tabular}

Defter oldur ki yeniçeri çayırından ocak ağalarına tevzî‘ olunan otlukdur ki zikr olunur. Der zamân-1 Ken'ân silâhdâr ağa-i şehriyâri sene 1069.

\begin{tabular}{|c|c|c|c|}
\hline $\begin{array}{l}\text { Hazret-i ağa } \\
\text { araba } 150 .\end{array}$ & $\begin{array}{l}\text { Kethüdâ-i } \\
\text { yeniçeriyân } \\
\text { araba } 30 .\end{array}$ & $\begin{array}{l}\text { Zağarcibaşı } \\
\text { araba } 20 .\end{array}$ & $\begin{array}{l}\text { Sersaksonc1 } \\
\text { araba } 20 .\end{array}$ \\
\hline $\begin{array}{l}\text { Serturnaci } \\
\text { araba } 15 .\end{array}$ & $\begin{array}{l}\text { Serçavuş } \\
\text { araba } 25 .\end{array}$ & $\begin{array}{c}\text { Muhzır ağa } \\
\text { araba } 15 .\end{array}$ & $\begin{array}{c}\text { Kethüdâ-i cây } \\
\text { araba } 15 .\end{array}$ \\
\hline $\begin{array}{c}\text { Çavuş-1 meyâne } \\
\text { araba } 10 .\end{array}$ & $\begin{array}{c}\text { Çavuş-1 küçük } \\
\text { araba } 8 .\end{array}$ & $\begin{array}{c}\text { Emin-i beytülmâl } \\
\text { araba } 10 .\end{array}$ & $\begin{array}{c}\text { Kâtib-i beytülmâl } \\
\text { araba } 5 .\end{array}$ \\
\hline $\begin{array}{c}\text { Kâtib-i kethüdâ-i } \\
\text { cây araba } 5 .\end{array}$ & $\begin{array}{c}\text { İmâm-1 ocak } \\
\text { araba } 5 . \\
\end{array}$ & $\begin{array}{c}\text { Kâtibân-1 baş } \\
\text { araba } 20 .\end{array}$ & $\begin{array}{c}\text { Kâtib-i kethüdâ } \\
\text { beg araba } 5 .\end{array}$ \\
\hline $\begin{array}{c}\text { Kethüdâ-i ağa } \\
\text { araba } 15 \\
\end{array}$ & $\begin{array}{c}\text { Kâtib-i dîvan } \\
\text { araba } 8 .\end{array}$ & $\begin{array}{c}\text { Nâzır-1 beytülmâl } \\
\text { araba } 5 .\end{array}$ & $\begin{array}{c}\text { Mirahûr-i ağa } \\
\text { araba } 5 .\end{array}$ \\
\hline $\begin{array}{c}\text { Vekilharc-1 ag̣ } \\
\text { araba } 3 .\end{array}$ & \multicolumn{2}{|c|}{$\begin{array}{c}\text { Emin-i şa'ir } \\
\text { araba } 3 .\end{array}$} & $\begin{array}{c}\text { Nâzır-1 odun } \\
\text { araba } 3 . \\
\end{array}$ \\
\hline
\end{tabular}

${ }^{45}$ Dört görevlinin akide miktarları yazılı değildir. 
Babanakkâş nâm mahalde yeniçeri ağasına mahsûs bir büyük çayır vardır. Beher sene zamânı geldikde altmış bir bölüklerden nevbetce ikişer bölükbaşı ta'yîn (olunur, çayırı biçerler, akçesin ol ta ${ }^{6} y$ n̂n ${ }^{46}$ olunan bölükbaşı ağalar kendi yanlarından virirler. Araba kirâların beytülmâl-i müslimînden virirler. Herkesin defteri mûcibince otlukları evlerine gelür. Kānûn kâ‘ide budur ki zikr ve işâret olunmuşdır. Devr-i ocakdan beri virilegeldiği muhakkakdır. Bu âna gelince tebdîl ve ta'yîn olunmamışdır, şöyle ma'lûm ola.(14a)

Sa‘âdetlü ve mehâbetlü pâdişâh-ı âlempenâh hazretleri Yeniçeri Ocağı'na rikâb-ı hümâyûn ağalarına beher sene ihsân eylediği bahâriye ve zemistânîyi beyân ider. Elvâki` sene 1054 .

\begin{tabular}{|c|c|c|c|}
\hline $\begin{array}{c}\text { Hazret-i ağa } \\
\text { hil'atı fâhire aded } \\
1 .\end{array}$ & $\begin{array}{c}\text { Sersekbânan } \\
\text { hil'atı fâhire aded } \\
1 .\end{array}$ & $\begin{array}{c}\text { Kâtib-i } \\
\text { yeniçeriyân } \\
\text { çuka adet } 1, \\
\text { kumaş aded } 1 .\end{array}$ & $\begin{array}{l}\text { Kethüdâ-i } \\
\text { yeniçeriyân } \\
\text { çuka aded } 1, \text { kumaş } \\
\quad \text { aded } 1 .\end{array}$ \\
\hline $\begin{array}{c}\text { Sersolak } \\
\text { çuka aded 1, } \\
\text { kumaş aded } 1 .\end{array}$ & $\begin{array}{c}\text { Sersolak } \\
\text { çuka aded } 1, \\
\text { kumaş aded } 1 .\end{array}$ & $\begin{array}{c}\text { Sersolak } \\
\text { çuka aded } 1 \text {, } \\
\text { kumaş aded } 1 .\end{array}$ & $\begin{array}{c}\text { Sersolak } \\
\text { çuka aded } 1, \text { kumaş } \\
\text { aded } 1 .\end{array}$ \\
\hline $\begin{array}{c}\text { Serzağarc1 } \\
\text { çuka aded 1, } \\
\text { kumaş aded } 1 .\end{array}$ & $\begin{array}{l}\text { Sersaksonc1 } \\
\text { çuka aded } 1 \text {, } \\
\text { kumaş aded } 1 .\end{array}$ & $\begin{array}{c}\text { Serturnaci } \\
\text { çuka aded 1, } \\
\text { kumaş aded } 1 .\end{array}$ & $\begin{array}{c}\text { Hâseki } 14 \\
\text { çuka aded } 1, \text { kumaş } \\
1 \text { aded } 1 . \\
\end{array}$ \\
\hline \multirow[t]{2}{*}{$\begin{array}{c}\text { Hâseki } 49 \\
\text { çuka aded 1, } \\
\text { kumaş aded } 1 .\end{array}$} & $\begin{array}{c}\text { Hâseki } 66 \\
\text { çuka aded } 1 \text {, } \\
\text { kumaş aded } 1 .\end{array}$ & $\begin{array}{c}\text { Hâseki } 67 \\
\text { çuka aded } 1 \text {, } \\
\text { kumaş aded } 1 .\end{array}$ & $\begin{array}{c}\text { Başçavuş } \\
\text { çuka aded } 1, \text { kumaş } \\
\text { aded } 1 .\end{array}$ \\
\hline & $\begin{array}{c}\text { Muhzır ağa } \\
\text { çuka aded 1, } \\
\text { kumaş aded } 1 .\end{array}$ & $\begin{array}{l}\text { Kethüdâ- cây } \\
\text { çuka aded 1, } \\
\text { kumaş. aded } 1\end{array}$ & \\
\hline
\end{tabular}

${ }^{46}$ Parantez içi kısım metin kenarına ilave edilmiştir. 


\section{Yeniçeri ağası tebdîl oldukda yeni ağaya ocak ağalarının verdiği pişkeşdir ki zikr olunur:}

\begin{tabular}{|c|c|c|c|c|c|}
\hline \multicolumn{2}{|c|}{$\begin{array}{c}\text { Hazret-i efendi } \\
\text { som 'abâyi aded } 1 .\end{array}$} & \multicolumn{2}{|c|}{$\begin{array}{l}\text { İstanbul ağas1 } \\
\text { zencir adet } 1, \\
\text { levha? aded } 1 .\end{array}$} & $\begin{array}{c}\text { Sersekbân } \\
\text { som 'abayi } \\
\text { aded } 1 . \\
\end{array}$ & $\begin{array}{l}\text { Kethüdâ beg } \\
\text { sîm dîvan rahtı } \\
\text { aded } 1 .\end{array}$ \\
\hline \multicolumn{2}{|c|}{$\begin{array}{c}\text { Serzağarî } \\
\text { serâser donluk } \\
\text { aded } 1, \text { kadife aded } \\
1 . \\
\end{array}$} & \multicolumn{2}{|c|}{$\begin{array}{c}\text { Sersaksoncu } \\
\text { serâser donluk aded } \\
1, \text { kadife aded } 1 .\end{array}$} & $\begin{array}{c}\text { Turnacibaşı } \\
\text { sîm özengi aded } \\
1 .\end{array}$ & $\begin{array}{r}\text { Hâsel } \\
\text { sâye çuk } \\
\text { kumaş }\end{array}$ \\
\hline \multicolumn{2}{|c|}{$\begin{array}{c}\text { Hâseki } 49 \\
\text { sâye çuka aded 1, } \\
\text { kumaş aded } 1 .\end{array}$} & \multicolumn{2}{|c|}{$\begin{array}{c}\text { Hâseki } 66 \\
\text { sâye çuka aded 1, } \\
\text { kumaş aded } 1 .\end{array}$} & $\begin{array}{c}\text { Hâseki } 67 \\
\text { sâye çuka aded } \\
1, \text { kumaş aded } 1 .\end{array}$ & $\begin{array}{c}\text { Başçavu } \\
1 \text { adet sîm eğer, } \\
\text { altun kenâne? } 1 \\
\text { aded. }\end{array}$ \\
\hline $\begin{array}{l}\text { Muhzır ağa } \\
\text { som 'abayi } \\
\text { aded } 1 .\end{array}$ & & & $\begin{array}{l}\text { Emîni } \\
\text { beytülmâl } \\
\text { Sîm palan } \\
\text { aded } 1 .\end{array}$ & $\begin{array}{c}\text { Çavuş-1 } \\
\text { meyâne sâye } \\
\text { çuka aded } 1 \text {, } \\
\text { kumaş aded } 1 .\end{array}$ & $\begin{array}{c}\text { Çavuş-1 küçük } \\
\text { sâye çuka aded } \\
1, \text { kumaş aded } \\
1 .\end{array}$ \\
\hline
\end{tabular}

Yeniçeri ağası tebdîl oldukda işbu bâlâda mesdûr olunduğu üzere ocak ağalarının virdügi pişkeş bu minvâl üzere virilegelmişdir tebdîl ta 'yîr olmaz.(14b)

Der-beyânı ibtidâ-yı ağayân-1 yeniçeriyân-1 dergâh-1 'âlî fî zamân-1 Sultân Selim Han aleyhi'r-rahmetü ve'r-rıdvân. Sene 921. Ma'lûm ola ki evâil-i Devlet-i Âl-i Osman' da yeniçeri tâ'ifesinin ağaları sekbânbaşı ve kulkethüdâları zağarcıbaşı idi. Fâtihu'l-Arab ve'l Acem olan merhûm ve ma'fûrunleh Sultân Selim Han hazretleri Acem seferinden avdet itdikde sefer-i sa'âdetleri sene dokuz yüz yirmi bir Receb'inin sekizinci güni azîm dîvan idüb Zeyrekzâde Rumili kâdı'askeri ve Tâcîzâde Ca'fer Çelebi Anadolu kâdı'askeri idiler ve ikisi ma'an içerü arza girüb bir mikdâr eğlenüb çıkdıklarında Rumili kâdı'askeri Zeyrekzâde yine yerinde karâr idüb kazâya istimâ' eyledi. Anadolu kâdı'askeri Ca'fer Çelebi evine gitdi. Ba'de Pîrî Paşa içerü arza girüb bir mikdâr eğlendi yine çıkub kapu önünde oturdu. Sekbânbaşıyı içerüden taleb eyledüler, Sekbânbaşı Balyemez Osman Ağa gelüb paşalar ile girü arza girdüler. Bir sehilden yine çıkub dîvânhânede oturdılar, sekbânbaşı içerüde kaldı. Ba'de kapucubaşı Behram Ağa acele ile gelüb dîvân-1 âlî içinde Pîrî Paşa'nın ve İskender Paşa'nın ellerin ardına bağlayub tekrâr pâdişâha getürdü. Ba'de zamân Anadolu kâdı' askeri olan Tâczâde Ca'fer Çelebi'yi çavuşlar 
varub evinden getürdiler, ol dahi doğru pâdişâha gidüp arza girdi. Az zamândan sonra Pîrî Paşa eli bağlu iken salıvirilmiş yalnız çıkub evine gitdi. Yanınca çavuşlardan ve gayri kimselerden bir ferd gitmeyüb men“ olundu. Azl olunub deryâdan Eyyüb cânibinde çiftliğine gitdi. Bir zamândan sonra cellâd taleb olunub ve birkaç kapucular mahall-i arz olan (15a) hücrenin demür kapusunda durub hünkârı temâşa idüb İskender Paşa'nın ve Ca'fer Çelebi'nin ve ba'de Balyemez demekle meşhûr Osman Ağa'nın boyunların urdular. Sabıkâ silâhdâr-1 pâdişâhı olub hala mir'âlem olan Ya'kub Ağa Yeniçeri Ocağı'na ağa nasb olunub istihdâm içün altmış bir bölükbaşı çorbacıyı otuz birer nefer ile tecdîd olunmuşdur. Bâlâda zikr olundığı üzere sabıkâ kulkethüdâsı zağarcıbaşı idi. Ba'de ağa bölüğide birinci bölükbaşı kethüdâ beg ta'yîn olunub beşinci bölükbaşı başçavuş ta'yîn olunub mecmû‘ üç çavuşdur. (Murûr-u eyyâm ile birer ikişer dahi vaz' olunub giderek) birkaç dahi olur oldu. Ve kānûn-1 kadîm bu idi ki yeniçeri kethüdâsı her gün ağakapusunda bulunub ocağa müte'allik da'vâyı ol görürdü ve iktizâ ideni ağaya arz idüb ba'de zamân a'dây-1 dîn üzerine serdârlar ta'yîn olunub ağa yerine kulkethüdâsı gidüb pâdişâhlar sefere gitmedikçe ağalar gitmezdi, kethüdâ beg yerine Âsitâne'de başbölükbaşı kâimmakâm kalub ocak umûrın ol görürüdü. Âhirülemr asâleten kethüdâ beg Âsitâne'de olduğı zamânda bile kethüdâyeri istihdâm olunub kethüdâ beg ancak umûrı mu'azzamaya karuşub gayriye tenezzül eylemez oldı. Ve kethüdâyerinin yolu muhzırlıkdır andan acemi yayabaşısı olub ba'de yolu geldükde kapu yayabaşısı olub ba'de deveci andan sonra hâseki, turnac1, saksonc1 ve zağarcı olub ba'de kethüdâ beg olur. Kānûn-1 kadîm üzere deveci dört ve hâseki üç idi ve kethüdâ begin yolu sancakdârlıkdır. İsterse sekbânbaşı olur ve sekbânbaşıların yolu yayabeglikdir ve sancakdâr. Ve pâdişâhlar sefere gitseler sekbânbaşı İstanbul'u beklemeğe me'murdur. Ocakda on dört yayabegliği vardır. Hâsıl-1 kelâm bu mukaddemeden murâd budur ki ibtidâ ocakda yeniçeri ağası (15b) ne tarîkile olmuşdır arz, anı beyândır. Çün Ya‘kub Ağa yeniçeri ağası oldı, Mısır fethinde çok yüz aklıkları eyledi.

Tevârîh-i ağay-1 yeniçeriyân-1 dergâh-1 'âlî. İbtidâyı ağay-1 yeniçeriyân Ya'kub Ağa sene 921. Mîr'âlem Ahmed Ağa sene 927. Mîr'âlem İsma'il Ağa sene 932. Silâhdâr-1 pâdişâhı Ca'fer Ağa sene 936. Mîr'âlem Yusuf Ağa sene 941.47 Başkapucu Ferhad Ağa sene 948. Silâhdâr-1 pâdişâhı Ahmed Ağa sene 956.

\footnotetext{
${ }^{47}$ Esad Efendi nr. 3622'de Mîr‘alem Sinan Ağa yazılıdır.
} 
Mîr'âlem Sinân Ağa sene $957 .{ }^{48}$ Mîr'âlem Mehmed Ağa sene 962. Başkapucubaş1 Kerim Ağa sene 966. Silâhdâr Mehmed Ağa sene 971. Mîr'âlem 'Ali Ağa sene 973. Kapucubaşı Ca'fer Ağa sene 975. Mîrahûr Siyavuş Ağa sene 976. Çerkes Mustafa Ağa sene 978. Ciğalazade Sinân Ağa sene 981. Cerrâh Mehmed Paşa sene 983. İbrahim Paşa fâtih-i Kıbrıs sene 984. Mîrahûr Ferhad Ağa sene 988. Mîr'âlem Yusuf Ağa sene 992. Mîrahûr Mehmed Ağa sene 993. Silâhdâr Ali Ağa sene 994. Mîrahûr Ca'fer Ağa sene 997. Mîr'alem Güzelce Mahmud Paşa sene $998 .{ }^{49}$ Sa a atci Hasan Ağa sene 999. Silâhdâr Halil Ağa sene 999. Mataracı Mehmed Ağa sene 1001. Kefe Lalası Mehmed Paşa sene 1002. Yemişçi Hasan Ağa sene 1002. Siyavuş Paşa damadı Ahmed Ağa sene $1003 .{ }^{50}$ Yemişçi Hasan Ağa (tekrar)sene 1005. Sarı Veli Ağa sene 1005. Sarıkçı Mustafa Ağa sene 1005. Tırnakçı Hasan Ağa sene 1005. Mîr'âlem Ali Ağa sene 1009. Bostancıbaş1 Ferhad Ağa sene 1011. Kapucubaşı Kasım Ağa sene 1012. Koca Ahmed Ağa sene 1013. Nakkâş Hasan Paşa sene 1013. Tırnakçı karındaşı Hüseyin Ağa sene 1014. Paryol ${ }^{51}$ Hüseyin Ağa (ibtida ocakdan ağa olan budur) sene $1015 .^{52}$ Duzakç1 ${ }^{53}$ Mehmed Ağa sene 1018. Mîrahûr İbrahim Ağa sene 1019. Mîr'âlem İsma'il Ağa sene 1020. Çukadâr-1 pâdişâhi Ahmed Ağa, sene 1021. Yavuz Muslihiddin Ağa (ocakda ağa iken fevt şüd) sene 1023. Mîrahûr Ahmed Ağa sene 1023. Musli Ağa (Revan'da şehid olmuşdur) sene 1024. Saksoncubaş1 Hüseyin Ağa sene 1025. Maktûl Hüseyin Paşa sene 1026.Borlulu Mustafa Ağa sene 1027.Silâhdâr Yusuf Ağa sene 1028. Niğdeli Mustafa Ağa sene 1029. Deveci Ali Ağa (Ocakda şehid şüd) 1030. Doğancı Deli Derviş Ağa sene 1031. (16a) Çukadâr Bayram Ağa sene 1031. Deli Derviş (tekrar) sene 1031. Mîrahûr Kara Mustafa Ağa 1031. Çeşte Ali Ağa (kethüdâ beglikden ağa oldi) sene 1032. Vezâretli Bayram Paşa (kethüdâ beg idi ağa oldi) sene 1032. Çukadâr Hüsrev Paşa vezâretli sene 1033. Çavuşbaşı Ali ağa sene 1035. Sipâhiler ağası Halil Ağa sene 1037. Mevlevi Mehmed Ağa sene 1037. Doğancibaş1 Mostarl1 Mustafa Ağa sene 1038. Hüsrev Paşa kethüdâsı Süleyman Ağa sene 1040. Hattat Hasan Ağa sene 1041. Musâhib Hasan Halife (Etmeydânı'nda yaralandı) sene 1041. Çukadâr Mustafa Ağa sene 1041. Köse Mehmed ağa (kethüda beg idi) sene 1041. Sipâhiler ağası Mehmed Ağa sene 1043. Sekbânbaşı Kara Mustafa Ağa

\footnotetext{
${ }^{48}$ Esad Efendi nr. 3622'de Mîr'alem Yusuf Ağa yazılıdır.

${ }^{49}$ Diğer iki nüshada bu ağadan evvel Halil Ağa (994) ve Hızır Ağa (997) gösterilmiştir.

${ }^{50}$ Esad Efendi nr. 3622'de Ahmed Ağa'dan önce Yemişçi Hasan Ağa'nın ilk ağalı̆̆ gösterilmemiştir.

${ }^{51}$ Diğer iki nüshada "Maryol" şeklinde yazılıdır.

${ }^{52}$ Esad Efendi nr. 3622'de Maryol Hüseyin Ağa'dan sonra Halil Ağa yazılmıştır.

${ }^{53}$ Esad Efendi nr. 3622'de "Duvakçı” Hasan Paşa 3165/3'de "Tarakçı” şeklinde yazılıdır.
} 
sene 1044. Mîrahûr Şahin Ağa sene 1045. Sekbânbaşı Küçük Hasan Ağa sene 1046. Rikâbdâr Mustafa Ağa sene 1049. Mîrahûr Tekyeli Mustafa Ağa sene 1049. Bektâş Ağa (ocakdan ağa oldi) sene 1051.(16b)

\section{KAYNAKÇA}

\section{ARŞIV KAYNAKLARI}

Başkanlık Osmanlı Arşivi (BOA)

BOA, Bâb-ı Âsafî, Nişan ve Tahvil Kalemi Defterleri (NŞT. d.), 1140.

BOA, Bâb-ı Âsafí, Ruus Kalemi Defterleri (A.RSK. d.),1484.

BOA, Kamil Kepeci Defterleri (KK. d.), 244.

BOA, Maliyeden Müdevver Defterler (MAD. d), 18155.

\section{KITAP VE MAKALELER}

III. Ahmed'in Hatt-ı Hümâyûn Mecmuası, (İstanbul Üniversitesi Kütüphanesi, TY, $n r .6094$, vrk. Ib-30a), (haz. Muhammed Dervişoğlu), İstanbul Üniversitesi Edebiyat Fakültesi Mezuniyet Tezi, İstanbul 1974, İstanbul Üniversitesi Kütüphanesi, no 10506.

Âsım Efendi Tarihi, I, (haz. Ziya Yılmazer), TYEKB Yayınları, İstanbul 2015.

Abdulkasim Gül, 18. Yüzyılda Yeniçeri Teşkilatı, Doktora Tezi, Atatürk Üniversitesi Türkiyat Araştırmaları Enstitüsü, Erzurum 2020.

Erzurumlu Osman Dede, Köprülüzâde Ahmed Paşa Devrinde (1069-1080) Vukuatı Tarihi, Transkripsiyon ve Değerlendirme, (haz. Arslan Boyraz),Yüksek Lisans Tezi, Marmara Üniversitesi Türkiyat Araştırmaları Enstitüsü,İstanbul 2002.

İsmail H. Uzunçarşı1l, Kapıkulu Ocakları, I, TTK Basımevi, Ankara 1988.

Koca Sekbanbaşı Risalesi, haz. Abdullah Uçman, Tercüman 1001 Temel Eser, Tarihsiz,

Osmanlı Kanunnâmeleri ve Hukukî Tahlilleri, IX, (haz. Ahmed Akgündüz), Osmanlı Araştırma Vakfı Yayınları, İstanbul 1994.

"Sadrıâzam Kemankeş Kara Mustafa Paşa Layihası", (haz. Faik Reşit Unat), Tarih Vesikaları, Nisan 1942, I/ 6, 443-480.

Selânikî Mustafa Efendi, Tarih-i Selânikî, I-II, (haz. Mehmet İpşirli), TTK Basımevi, Ankara 1999.

Seyyid Lokman, Tomar-ı Hümayûn, Topkapı Sarayı Müzesi Kütüphanesi, Hazine nr. 1321.

Yeniçeri Ocağına İlişkin Bir Risale, Süleymaniye Kütüphanesi, Esad Efendi, nr. 3622. 